\title{
Commons Management in Migrant Communities
}

\section{GODFREYB SSEKAJJA (D)}

\section{]u[ubiquity press}

\begin{abstract}
This article examines whether (and why) migrant communities are less likely to support institutions for managing common pool resources. Focusing on Buvuma Island, which is situated in Uganda's portion of Lake Victoria, I study the efforts at locally supporting forestry regulations among randomly selected communities. These communities have varying proportions of both immigrants and prospective out-migrants, and they are confronting the degradation of adjacent forest reserves. The evidence from survey data on 293 randomly selected heads of households suggests that migrant communities are less likely to support common pool resource institutions. The same evidence suggests that the lower likelihood of support among migrant communities has more to do with their weaker relationships (of reputation, trust, and reciprocity) than their expectations about the institutional net-benefits.
\end{abstract}

CORRESPONDING AUTHOR:

\section{Godfreyb Ssekajja}

Indiana University Bloomington, USA

gssekajj@iu.edu

\section{KEYWORDS:}

migration; common-pool resources; forest management; common property institutions

TO CITE THIS ARTICLE:

Ssekajja, G. (2021). Commons Management in Migrant Communities. International Journal of the Commons, 15(1), pp. 132-153. DOI: https://doi. org/10.5334/ijc.1079 


\section{INTRODUCTION}

An underexamined question for social scientists is whether migrant communities are less likely to support institutions for common pool resource management. ${ }^{1}$ A significant body of literature suggests that immigration (Curran \& Agardy, 2002; Katz, 2000) and out-migration (Rudel, 2011; Robson \& Berkes, 2011; Wang et al, 2016) undermine institutional processes in local communities. ${ }^{2}$ However, the likelihood of successful institutions for common pool resource management among migrant communities remains poorly understood. For example, although many prominent explanations emphasize the "past-based" determinants of collective action for common pool resource management, such as the core relationships of reputation, trust, and reciprocity (Ostrom et al, 1994; Andersson, 2004; McKean et al, 2000; Ostrom, 2010; Pretty \& Ward, 2001), some studies suggest that new immigrant communities, with no prior interactions, can engage in collective action to support institutions for managing common resources (Anderson \& Hill, 2004; Alston et al, 1996; McDowell, 2002; Clay \& Wright, 2005; Alston et al, 2012).

This article attempts to explain whether immigrant communities are less likely to engage in collective action to support institutions for common pool resource management, and if so, what are the likely underlying mechanisms? The focus is on communities with varying proportions of both immigrants and prospective outmigrants. This enables consideration of whether the migrants' "past-based" experiences exert more influence on the collective action than their "future-based" expectations. For clarity, consider a new community of immigrants, with no prior interactions and low prospects of out-migrating. If such a community acts collectively to support institutions for common pool resource management, then one could logically posit that expectations about benefits from institutions, without prior communal interactions, are sufficient to engender the collective action. Alternatively, if such a community fails to act collectively, one could logically posit that without prior interactions among community members, expectations about institutional benefits are not sufficient to engender the collective action. The latter argument stresses the role of "past-based" determinants of collective action while the former does not.

The main hypothesis of this article is that new communities of immigrants are less likely to engage in collective action to support institutions for forestry resource management. To test this hypothesis, I focus on Buvuma Island, which is situated in Uganda's portion of Lake Victoria, to study efforts at locally supporting national forestry regulations in twelve randomly selected communities that are confronting the degradation of adjacent forest reserves. Among the reasons for selecting this Island is the fact that the proportions of migrants among its communities vary sufficiently to enable comparative analysis. ${ }^{3}$ I classify communities, based on how local residents commonly differentiate settlements around migration, into: (1) "old villages", with low proportions of both immigrants and prospective out-migrants; (2) "new villages", with high proportions of immigrants but low proportions of prospective out-migrants; and (3) "camps", which are largely transitory, with high proportions of both immigrants and prospective out-migrants. That said, my analysis of migratory impacts on Buvuma Island is designed to sufficiently consider alternative explanations of local forestry institutional processes.

The communities on Buvuma Island are microcosmic of the communities of all Lake Victoria Islands so that this study can shed light on those other cases. As with Buvuma Island, most Lake Victoria communities possess several prerequisites for successful common pool resource institutions (Ostrom, 1990; Wade, 1987; Agrawal, 2001), such as small populations of interdependent individuals, shared languages that foster communication, small territories that enable interpersonal contact, clearly defined boundaries that facilitate the exclusion of outsiders, and geographical isolation that limits external interference in local affairs. The puzzle is that these communities are also riddled with chronic cases of forestry destruction, fisheries overexploitation, and other manifestations of failed common pool resource management. Several studies associate migration with the resource misappropriation and livelihood challenges in these lake communities (Nunan, 2010; Allison \& Ellis, 2001; Matsuishi et al, 2006; Silsbe \& Hecky, 2008). However, the impacts of migration flows on institutional processes (and the likelihood of institutional processes among migrant communities) are usually ignored in prior studies.

This article builds on existing literature to make three contributions. First, it presents evidence suggesting that new immigrant communities are less likely to support common pool resource institutions. Second, it presents additional evidence of an underlying explanation; that new immigrant communities have not had sufficient time to develop relationships (of reputation, trust, and reciprocity) that are necessary to engender collective action for institutional support. Third, it provides the first field study (to my knowledge) about possible determinants of institutions for natural resource management that explicitly compares the explanatory powers of interpretations of "past-based" experiences visà-vis "future-based" expectations. ${ }^{4}$ 


\section{MIGRANT COMMUNITIES AND INSTITUTIONS FOR COMMONS MANAGEMENT}

Most prominent studies on community self-organization for common pool resource management emphasize the role of "past-based" explanations of behavioral patterns: individuals confronting common pool resource dilemmas are usually modeled as adaptive creatures with normative behavior that is acquired from experiences (Ostrom et al, 1994; McKean et al, 2000; Pretty \& Ward, 2000; Ostrom, 2000; Andersson, 2004). Thus, explanations of support to the institutions for common pool resource management depart from the rational actor theory, which is often used to explain how individuals achieve close to optimal outcomes in competitive market settings. In fact, at the core of an evolving theoretical explanation of successful collective action for common pool resource management is the emphasis on social capital (Ostrom \& Ahn, 2009) and the argument that when individuals acquire a reputation for positive reciprocity, others can then learn to trust those with such a reputation and begin to cooperate (Ostrom, 2010). This argument is also evident in studies on the adverse impacts of in-migration (Curran \& Agardy, 2002; Katz, 2000) and out-migration (Rudel, 2011; Robson \& Berkes, 2011; Wang et al, 2016).

But some other studies suggest that collective action for common resource management is possible among new immigrant communities with no prior interactions, and thus no "past-based" relationships of reputation, trust, and reciprocity. This suggestion is most elaborately made by studies of regulatory regimes in frontier communities (Anderson \& Hill, 2004; Alston et al, 1996; McDowell, 2002; Clay \& Wright, 2011; Alston et al, 2012). ${ }^{5}$ That said, such studies are unlikely to shed light on the likelihood of effective common pool resource institutions among migrant communities because: (1) they often focus on private-individual property rights yet, when applied to common pool resources, such property rights tend to be more limited, correlative, contingent, and attenuated (Cole \& Ostrom, 2012); and (2) there are multiple interpretive lenses through which they describe the regulatory regimes- for example, the miners' codes adopted during the California gold rush are variously explained as spontaneously organized property regimes (Umbeck 1981), agreements based on shared mental models (Zerbe \& Anderson, 2001), governance regimes more complex than simple contracts for property rights (Clay and Wright 2005), or attempted solutions to coordination games based on a wider variety of norms (McDowell 2002).

To understand whether migrant communities are less likely to support institutions for common pool resource management, this article analyzes forestry institutions. Most studies that associate migration with deforestation do not explicitly consider institutions (Amacher et al, 2009; Mulley et al, 2004; Bilsborrow, 2002; Angelson, 1999; Shively, 2002; De Janvry et al, 2015; Pagdee et al, 2006). Instead, those studies tend to directly link migration to expanding agriculture and increased logging. Where forestry institutions among migrant communities are considered, the role of the previously noted "past-based" explanations of institutional processes is often sidelined. For example, Rudel (2011) suggests that, among prospective out-migrants, the anticipation of higher wages elsewhere reduces the salience of a resource to their livelihoods and raises the discount rates of supporting common pool resource institutions. This suggestion is plausible, but such attention to migratory effects on cost-benefit estimations neglects the role that relationships of reputation, trust, and reciprocity play in institutional processes (Ostrom, 1999; 2000; 2010).

I hypothesize that new communities of immigrants are less likely to engage in collective action to support institutions for common pool resource management. Accordingly, (1) such collective action is engendered by relationships of reputation, trust, and reciprocity, (2) those core relationships are developed through communal interactions over long periods and, (3) new immigrant communities have not had time to engage in such interactions as to develop the core relationships. ${ }^{6}$ Underlying these hypotheses is another assumption that the new immigrants did not move from the same geographical point of origin; otherwise they could have developed relationships of reputation, trust, and reciprocity long before arriving in the new community.

\section{CASE STUDY: FOREST RESERVE MANAGEMENT ON BUVUMA ISLAND}

Buvuma Island is located in Uganda, just a few kilometers off the northern shores of Lake Victoria (see Figure 1). ${ }^{7}$ It contains roughly 40,000 people and 56 villages (Timbuka, 2018). The communities on Buvuma Island are ideal for a study of whether and how migration affects support for forestry institutions largely because they vary with regards to the proportions of migrants. Moreover, the twenty-one forest reserves on Buvuma Island manifest differing levels of human encroachment and thus, are suited for a study on the determinants of forestry institutions.

Over the last two decades, the Island has witnessed forest destruction on an unprecedented scale. Global Forest Watch, an open-source web that monitors forests in near real-time, notes that $40 \%$ of its tree cover with a 


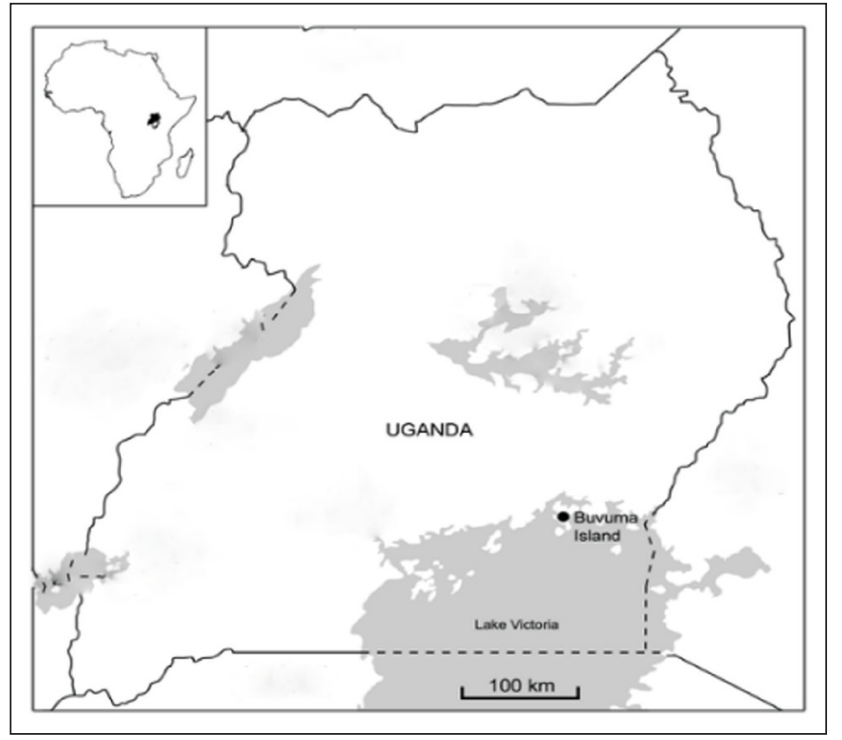

Figure 1 Location of Buvuma Island.

canopy density of over 10\% was lost between 2000 and 2018. ${ }^{8}$ Nangendo (2018) reveals that, by 2015, the fully stocked tropical high forest (which covered 53\% and 50\% of the Island in 1990 and 2000 respectively) had been largely destroyed. The key drivers of these changes are (1) tree harvesting for timber, fuelwood, and charcoal and, (2) subsistence farming and human settlement in forest areas. The National Forestry Authority (NFA) officials stress that among these drivers, charcoal making, and timber harvesting have had a far larger impact. These officials also consider the lost valuable trees- which can produce timber and charcoal-to estimate the percentage of a forest reserve degraded between 2000 and 2018 (see Table 1). Their estimations seem somewhat validated by a 2015 land cover map (Timbuka, 2018) or, the shades of color of forest reserves on any recent satellite map (see Appendix, Figure 8).

The Uganda National Forestry \& Tree Planting Act 2003 (UNFTPA) specifies regulations for curbing timber logging, charcoal making, agriculture and, human settlement in the forest reserves. The same act authorizes the National Forestry Authority (NFA) and the District Forestry Authority (DFA) to monitor and enforce the regulations in the forestry reserves. However, both authorities are too weak to independently carry out this mandate. For example, the local NFA bureau has only three personnel who are tasked to monitor and enforce regulations for a forestry area of over 4000 hectares. And, as per the 2019/20 financial year, the DFA operates on a meager budget of $\$ 4,000$. Such weaknesses imply that the enforcement of UNFTPA regulations largely depends on supportive efforts in the communities that are adjacent to the forest reserves.

On an Island with communities that are highly dependent on natural resources, local support for national forestry regulations is primarily a survival strategy to achieve long-term livelihoods. First, the forests are a critical source of fuelwood, water, timber, medicinal plants, and wildlife so that forestry institutions are seen as useful for safeguarding those benefits. Second, there is widespread acknowledgment that forestry institutions are indispensable for averting human-induced climate change, which is already impacting the region (Wandiga et al, 2010; Hepworth \& Goulden, 2008: 9-20). Many locals poignantly relate the forest loss of the past 20 years to the witnessed changes in temperatures, rainfall patterns, and water levels in Lake Victoria. Thirdly, some benefits seem confined to specific communities, such as the symbolic

\begin{tabular}{lccl}
\hline Forest reserve & Forest area (hectares) & Percentage degraded & Adjacent Communities** \\
\hline Bukaibale & 980 & $100 \%$ & Wabivu (C), Kirongo (C), Galigatya (N) \\
\hline Kakonwa & 700 & $100 \%$ & Kitiko (N), Kabubu (N), Bukiyindi (N) \\
\hline Olamusa & 380 & $60 \%$ & Namugombe (C), Kifulu (C), Mubale (C), Kasali B (C) \\
\hline Bira & 353 & $30 \%$. & Kyanamu (C), Bukayo (O), Bulima (O), Busamuzi (O) \\
\hline Buloba & 309 & $10 \%$ & Kitamiro (O), Walwanda (O), Buwanga (O), Bukambe (O) \\
\hline Bugusa & 283 & $80 \%$ & Mayinja (N), Bugabo (N) \\
\hline Kojja & 271 & $60 \%$ & Itojwe (C), Kachanga (C) \\
\hline Sozi & 260 & $50 \%$ & Galamo (C), Bukagali (N), Ziba (O), Bulima (O) \\
\hline Namabowe & 170 & $15 \%$ & Butabula (O), Bugongo (O), Bugema (O) \\
\hline Nakunyi & 151 & $10 \%$ & Magyo (O), Kitamiro (O) \\
\hline
\end{tabular}

Table 1 Characteristics of some forest reserves on Buvuma Island.

Notes: Forest area and percentage degraded are estimates provided by the NFA office on Buvuma.

${ }^{* *} \mathrm{C}, \mathrm{N}$, and $\mathrm{V}$ are abbreviations for 'camp', 'new village' and 'old village' (see later section for explanations). 
functions ascribed to adjacent forests by many residents in the communities of Bukayo and Magyo.

To support UNFTPA regulations, efforts are undertaken by adjacent communities to sustainably manage a forest reserve. Such efforts take two distinct forms. The first involves the formation of forestry committees (FCS). These committees are fundamentally local initiatives whose creation is not aided by external agents. In these committees, community members guarantee among themselves to manage a forest reserve, and they define specific informal rules for supplementing the UNFTPA regulations. ${ }^{9}$ Of the forest reserves in Table 1, only Bira, Buloba, Namabowe, and Nakunyi have FCs. The second form of sustainably managing forest reserves involves the formation of collaborative forestry organizations (CFOs). As the name suggests, CFOs are collaborative efforts for forest management between the NFA and local communities. However, although the CFOs on Buvuma ostensibly attempt to support UNTPA regulations, the rules they define tend to foster forestry destruction..$^{10}$ of the forest reserves in Table 1, only Bukaibale, Kakonwa, Olamusa, Bugusa, Kojja and Sozi have (or have ever had) CFOs.

\section{DATA COLLECTION \\ SAMPLING THE COMMUNITIES}

The empirical analysis largely relies on survey data collected between May and July (2019) from randomly selected heads of households in a target sample of communities on Buvuma Island. However, because my research purposes necessitate that the proportions of both immigrants and prospective out-migrants vary substantially among the communities, yet migratory patterns on Buvuma Island have not been previously documented, I carried out a preliminary survey in May 20018-during which I interviewed 52 leaders of 52 different communities on the Island. ${ }^{11}$ After these interviews, I classified 40 communities by their suggested differences in proportions of both immigrants and prospective out-migrants. ${ }^{12}$ I based the classification on how Island residents commonly differentiate settlements around migration, making distinctions between "camps", "old villages", and "new villages" (see Table 2). ${ }^{13}$ These community types also generally correspond with the longevity of the settlements, which is confirmed by the interview data.

Camps consist of make-shift accommodations of rickety shacks and mud huts. A typical camp is originally established when a landowner leases land on condition that the new settlers do not erect permanent structures on it. This "restricted leasehold" is associated with a migratory tendency among residents; arguably because the land tenure system implies that individuals- who are usually attracted by the region's fish stocks and fertile soils- have no incentive to plan for permanent residency. ${ }^{14}$ Instead, as the chairperson of the Itojwe community told me, they usually:

"Migrate (to the camps) with the intention of migrating out as soon as they can obtain a sufficient income... just like many Ugandan economic migrants to overseas countries".

On the other hand, residents of 'villages' can obtain freehold land tenure and, where they reside on leased land, can erect permanent structures. This possibility of property ownership is associated with sedentism (a tendency of community members to live in one place for a long time).

However, perhaps because wealth accumulation takes time, accommodation structures in the villages differ depending on how old a village is: permanent structures (brick-walled and iron-roofed) are more common in villages that were established more than five decades ago. Such structures are rare in 'new villages', most of which got established during the first decade of this century- largely due to an immigration wave triggered by factors such as rising fish prices and population pressures elsewhere. Crucially, these 'new villages' represent a distinct community type: for, unlike 'camps', most of their residents do not plan to emigrate. But, unlike in the 'old villages', most of their residents are not natives: they immigrated during the past few years.

With the 40 classified communities, I eliminated those not located within a kilometer of a forest reserve. That left me with 29 communities (see Table 1) from which I randomly selected 4 of each community type to create the target

\begin{tabular}{lcc}
\hline & Proportion of immigrants & The proportion of prospective out-migrants \\
\hline Camp & High & High \\
\hline New village & High & Low \\
\hline Old village & Low & Low \\
\hline
\end{tabular}

Table 2 Community Typology. 
sample of communities for further data collection (see Table 3). ${ }^{15}$ Note that although the community types differ by other characteristics besides migration, my analysis is designed to sufficiently consider alternative explanations of forestry institutional processes. ${ }^{16}$ For instance, a comparison of the camps, where most residents do not have secure tenure, with the new villages, where most residents have secure tenure, can be useful for averting concerns that could arise if insecure tenure were to explain both the high proportions of migrants and the low levels of communal support for forestry institutional processes.

\section{SAMPLING THE HOUSEHOLDS}

Point sampling was used to select 30 heads of households from each community. This involved randomly marking houses on a map. When an enumerator physically arrived at a marked house, he verified if it is a household (and not some other building) before sampling it. After that sampling, the enumerator requested to talk to the head of household. If that person was not present, he requested for his or her phone contact. Then, the enumerator would proceed to (1) introduce himself to the head of household, (2) explain both the purpose of the study and the process of recruiting subjects and, (3) seek his or her consent to participate in the survey. Of the sampled 360 heads of households, 37 refused to participate in the study. Eventually, of the 323 heads of households who were willing to participate, 293 actually participated.

To ensure that nonresponse biases do not generate samples that look very different from the population, the enumerators recorded "the presence of a solar panel (an indicator of affluence on an Island with no connection to the national electricity grid)" and "the gender of the head of household" for every household visited. Table 4 explores

\begin{tabular}{|c|c|c|c|c|c|c|}
\hline Community & $\begin{array}{l}\text { Community } \\
\text { type }\end{array}$ & $\begin{array}{l}\text { When } \\
\text { community } \\
\text { was first } \\
\text { established }\end{array}$ & $\begin{array}{l}\text { Main land tenure } \\
\text { arrangement }\end{array}$ & $\begin{array}{l}\text { Estimated } \\
\% \text { of } \\
\text { permanent } \\
\text { houses }\end{array}$ & $\begin{array}{l}\text { Estimated No. } \\
\text { of households }\end{array}$ & $\begin{array}{l}\text { Adjacent } \\
\text { Forest reserve(s) }\end{array}$ \\
\hline Mubale & Camp & Early 1970 s & "Restricted leasehold" & $0 \%$ & 170 & Olamusa \\
\hline Namagombe & Camp & Late 1980s & "Restricted leasehold" & $0 \%$ & 120 & Olamusa \\
\hline Itojwe & Camp & Mid 1980s & "Restricted leasehold" & $0 \%$ & 130 & Kojja \\
\hline Wabivu & Camp & Mid 1990s & "Restricted leasehold" & $0 \%$ & 190 & Bukaibale \\
\hline Kitamiro & Old village & Before 1960 & Freehold \& leasehold & $80 \%$ & 100 & Buloba \& Nakunyi \\
\hline Bukayo & Old village & Before 1960 & Freehold \& leasehold & $70 \%$ & 80 & Bira \\
\hline Magyo & Old village & Before 1960 & Freehold \& leasehold & $90 \%$ & 110 & Nakunyi \\
\hline Butabula & Old village & Before 1960 & Freehold \& leasehold & $85 \%$ & 90 & Namabowe \\
\hline Kitiko & New village & 2009 & Leasehold & $5 \%$ & 190 & Kakonwa \\
\hline Kabubu & New village & 2004 & Freehold \& leasehold & $5 \%$ & 90 & Kakonwa \\
\hline Mayinja & New village & 2006 & Leasehold & $2 \%$ & 100 & Bugusa \\
\hline Bukagali & New village & 2005 & Freehold \& leasehold & $8 \%$ & 120 & Sozi \\
\hline
\end{tabular}

Table 3 Characteristics of the sampled communities. ${ }^{17}$

\begin{tabular}{lcccc}
\hline Sample & Overall & Participated & Was willing but did not participate & Refused to participate \\
\hline Solar (1 = solar panel) & 0.67 & 0.66 & 0.66 & 0.70 \\
& $(0.02)$ & $(0.02)$ & $(0.09)$ & $(0.08)$ \\
\hline Share of men & 0.69 & 0.67 & 0.76 & 0.78 \\
& $(0.02)$ & $(0.03)$ & $(0.08)$ & $(0.07)$ \\
\hline Number of observations & 360 & 293 & 30 & 37 \\
\hline
\end{tabular}

Table 4 Sampling characteristics.

Notes: Standard errors are in parentheses. The share of men is a continuous variable. Solar is measured as a binary variable with the indicated category taking the value 1 , and 0 otherwise. 
the extent to which nonresponse is problematic. Notably, men were likely to be more nonresponsive than women. But the differences are not significant at conventional levels and, I generally had no reason to believe that the nonresponse patterns are a cause for concern to the results of my data analysis.

\section{SURVEY QUESTIONNAIRE}

A draft of the face-to-face questionnaire was pre-tested with four assistants in a randomly selected community and, irrelevant or ambiguous questions were deleted or modified to produce a final version. In addition to capturing data on socio-economic and demographic aspects, the final version included the following items to measure attitudes concerning forestry rules:

- To conserve forest reserves, several rules have been designed by the central government to limit human activities in the forest reserves. Do you generally support or oppose those rules (Respondents were asked to denote their support or opposition; responses were measured on a five-point Likert scale that ranged from "strongly support" to "strongly oppose")?

- Do you agree that other members of your community can generally be trusted to support the central government rules for limiting human activities in the forest reserves (Respondents were asked to denote their agreement or disagreement; responses were measured on a five-point Likert scale ranging from "strongly agree" to "strongly disagree")? ${ }^{18}$

Note that the above questions focus on forestry regulations designed by the central government, instead of the previously described forestry regulations that are designed by adjacent local communities to supplement UNTPA regulations. This is due to the following interrelated reasons: (1) I sought to have similar questions for capturing the respondents' attitudes, yet the forestry regulations drafted by the communities of Buvuma Island differ fundamentally (as elaborated in a previous section); (2) the governmental forestry regulations that I consider are already defined in the UNFTPA, and are widely known by the local residents; and, (3) since the locally defined forestry regulations principally aim to enforce governmental regulations, a focus on attitudes towards the latter serves as a reasonable indicator of attitudes towards the former.

Later in the questionnaire, each respondent was asked a series of questions to capture the characteristics of migration (See Appendix, Tables $9 \& 10$ ). For example, the questions to capture the characteristics of emigration included: "Do you plan to emigrate from this community?", "Is your next place of residence outside Buvuma Island?" and, "Why do you plan to emigrate?" To ensure locally relevant answers, all interviews were conducted in Luganda- a language that is widely understood, even by those who do not self-identify with the Ganda ethnic group. To be sure, it also helped that the main local languages (Luganda and Lusoga) are mutually intelligible.

\section{RESULTS}

I first analyze the characteristics of immigrants and prospective out-migrants (see Tables 9 and 10). For the immigrants, $97 \%$ moved from places of origins located outside the Island; $99 \%$ moved individually or as part of a household (only $1 \%$ moved as part of a group that is not a household); $92 \%$ moved to seek better economic opportunities. Secondly, as indicated in Table 10, the probability that two immigrants (selected at random from a community) migrated from the same geographical point of origin (here defined as a Ugandan district) does not exceed $32.5 \%$ for any of the 12 communities. ${ }^{19}$ Furthermore, for prospective out-migrants, 99\% plan to move to a place located outside the Island; $100 \%$ plan to move individually or as part of a household; $62 \%$ plan to emigrate to return home (this suggests that many prospective out-migrants do not consider the Island "home"), while only $25 \%$ plan to out-migrate to seek better economic opportunities.

Next, I analyze the community typology that informed my research design to ascertain whether the proportion of immigrants and the proportion of out-migrants vary as suggested, in addition to examining both the average duration of residency among community members, and whether residents have attachments [such as a spouse or child (ren)] in other communities. The latter two considerations are important because they enable analyses of other reasonable implications of the community typology. That is, if a community has a lower proportion of immigrants, one should reasonably expect that its mostly native-born (1) have, on the average, resided in the community for a longer duration of time, and (2) have less social attachments [such as a spouse or child (ren)] to other communities, besides their community of residency.

Figures 2 to 5 reveal suggestive evidence of strong support for the community typology. For example, 72\% of respondents in 'old villages' were born in the local community compared to only $4 \%$ and $0 \%$ for 'camps' and 'new villages' respectively. Second, $84 \%$ of respondents in 'camps' plan to emigrate compared to only $7 \%$ and 


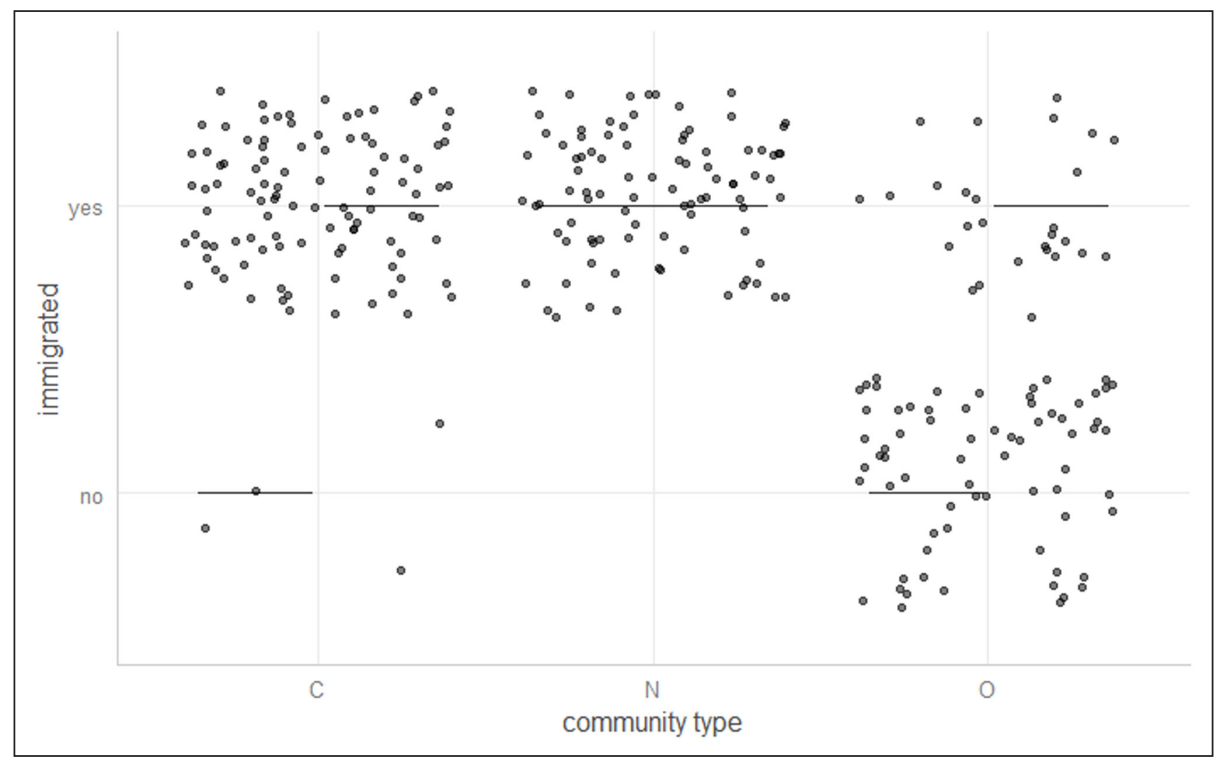

Figure 2 Did you immigrate to this community? (yes, no). Notes: $\mathrm{C}$ is camp, $\mathrm{N}$ is new village and $\mathrm{O}$ is old village.

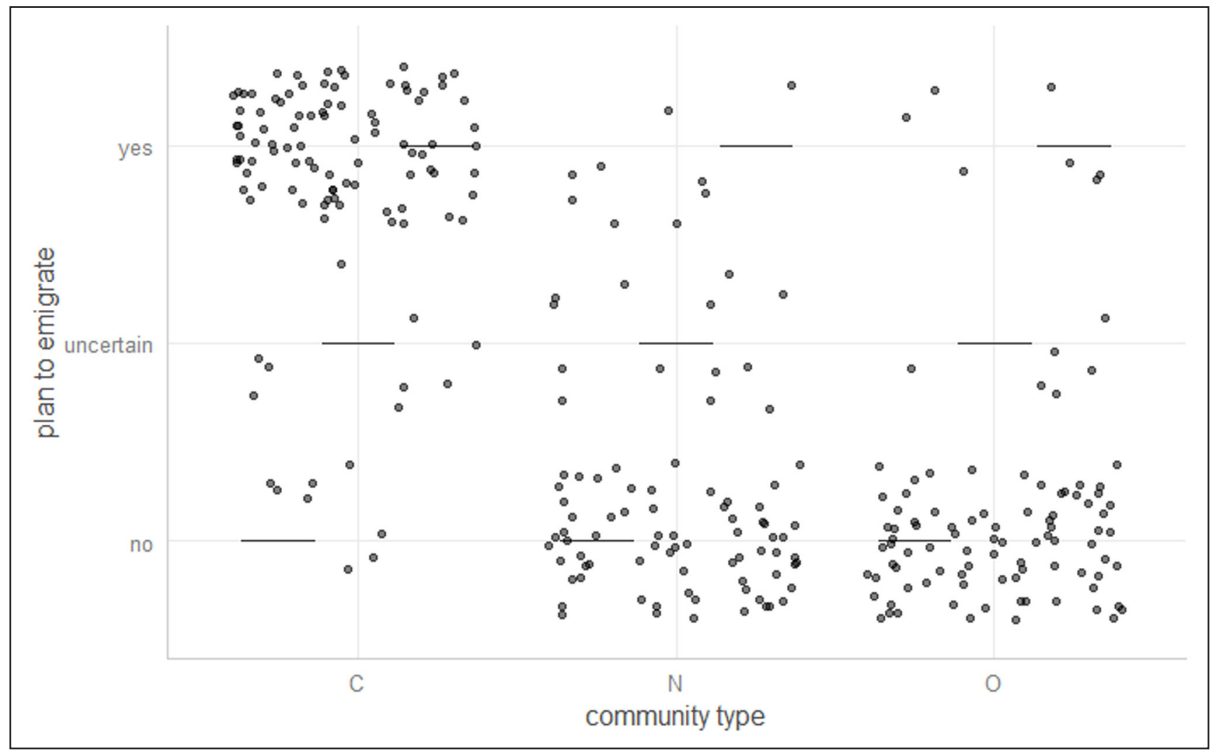

Figure 3 Do you plan to migrate out of this community? (yes, uncertain, no).

Notes: $\mathrm{C}$ is camp, $\mathrm{N}$ is new village and $\mathrm{O}$ is old village.

$10 \%$ for 'old villages' and 'new villages' respectively. Third, only $8 \%$ of respondents in 'old villages' have spouses or children outside the local community compared to $66 \%$ and $30 \%$ in 'camps' and 'new villages' respectively. Fourth, the average number of years that respondents have resided in 'camps' and 'old villages' is 4.53 and 5.1 respectively, compared to 29.7 in 'old villages'. Fifth, 97\% of respondents in 'old villages' have resided in the local community for 3 or more years compared to only $63 \%$ and $67 \%$ in 'camps' and 'new villages' respectively. Sixth,
93\% of respondents in 'old villages' have resided in the local community for 5 or more years compared to only $36 \%$ and $39 \%$ in 'camps' and 'new villages' respectively. Seventh, $82 \%$ of respondents in 'old villages' have resided in the local community for 10 or more years compared to only $14 \%$ and $12 \%$ in 'camps' and 'new villages' respectively.

To begin my evaluation of the impact of migration on the attitudes of individuals in the three community types, I compare the support for forestry rules across 


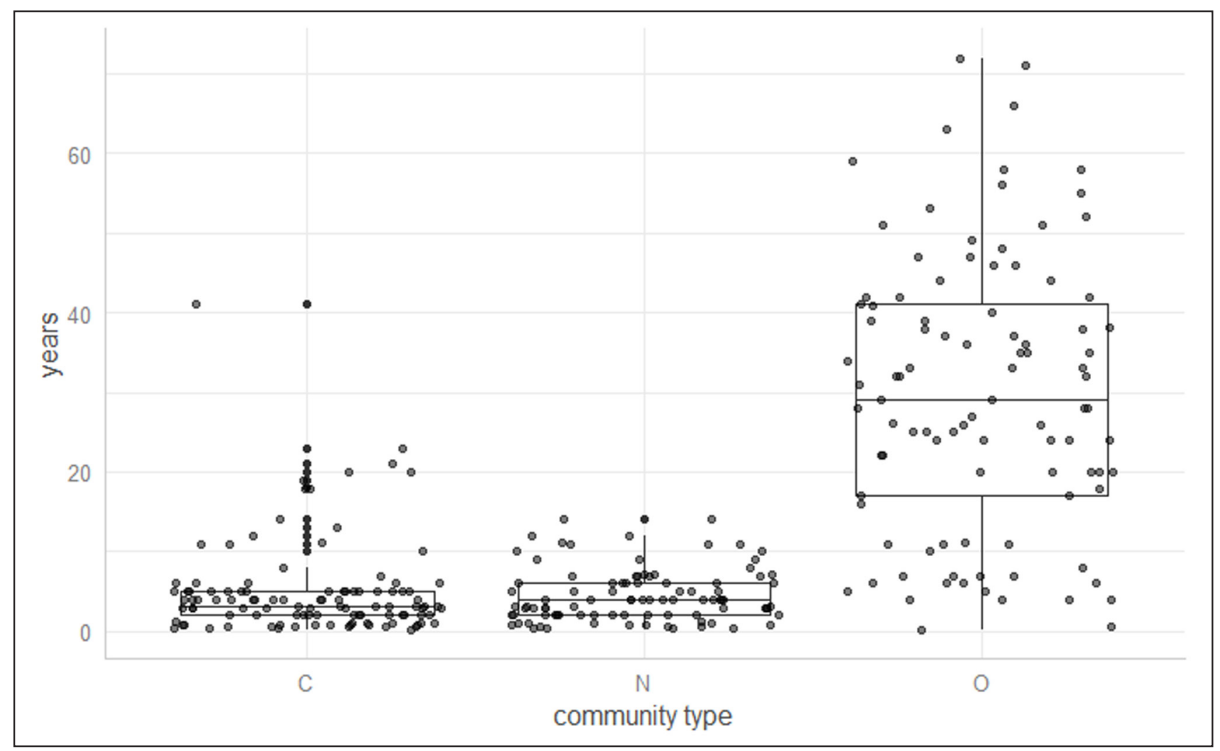

Figure 4 How long have you resided in this community? (years).

Notes: $\mathrm{C}$ is camp, $\mathrm{N}$ is new village and $\mathrm{O}$ is old village.

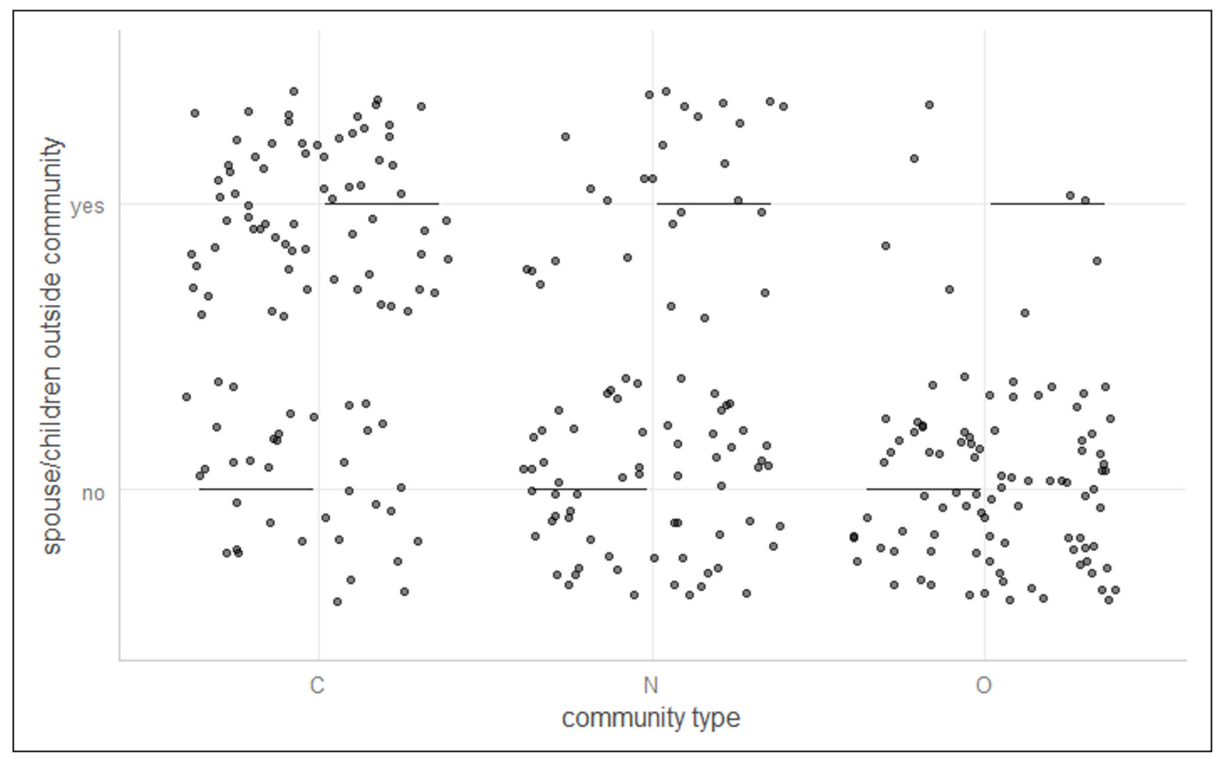

Figure 5 Do you have a spouse or child (ren) in other communities? (yes, no).

Notes: $\mathrm{C}$ is camp, $\mathrm{N}$ is new village and $\mathrm{O}$ is old village.

community types (see Figure 6). The level of support is substantively higher (89.4\%) for respondents in 'old villages' than those in 'camps' (53.8\%) or "new villages" $(48.4 \%)$. And, even though the level of support is higher for respondents residing in camps than those residing in new villages, that difference is not substantial. Relatedly, when I compare trust -that other community members support forest rules- (see Figure 7), I find that the level of trust is substantively higher (84.8\%) for respondents residing in 'old villages' than those in 'camps' (36.0\%) or "new villages" (40.8\%).
To analyze the predictors of 'support for forestry rules' and 'trust that other community members support forestry rules', I utilize ordered logistic regression analysis given the ordinal nature of my Likert scale questions. The control variables are described in Table 5, while the multivariate analyses are illustrated in Table 6. In models 1 and 2 of Table 6, residency in an old village is the baseline relative to which both residency in a camp and residency in a new village are analyzed. Notably, data from my preliminary field study also sheds light on the "possible alternative explanations". For example, the information gathered from local leaders 


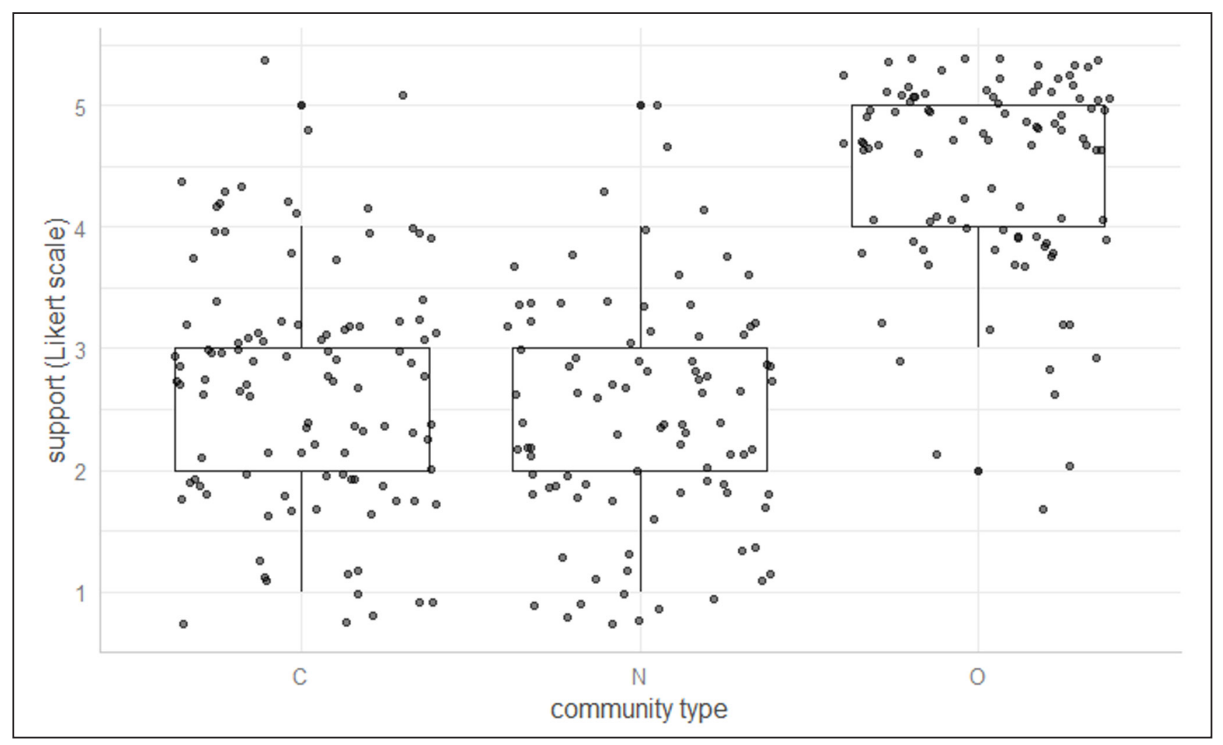

Figure 6 Support for governmental forest rules.

Notes: $\mathrm{C}$ is camp, $\mathrm{N}$ is new village and $\mathrm{O}$ is old village.

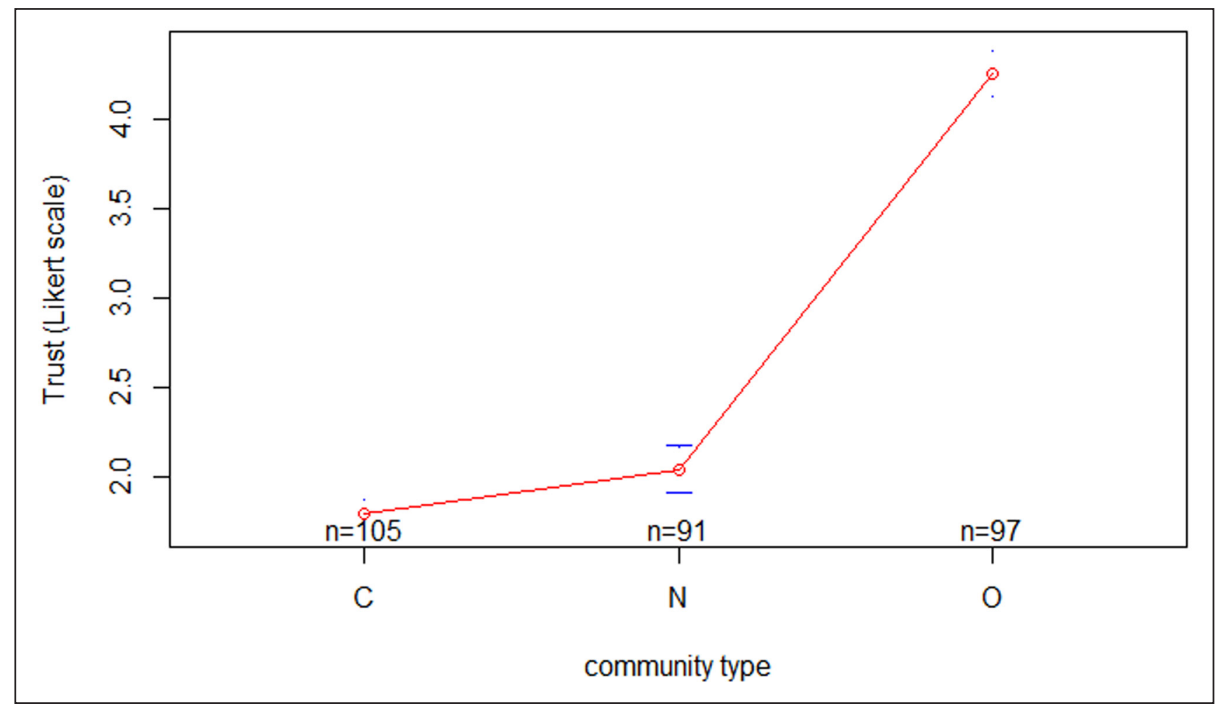

Figure 7 Trust that others support governmental forest rules.

Notes: $\mathrm{C}$ is camp, $\mathrm{N}$ is new village and $\mathrm{O}$ is old village.

reveals that the 'extent of forestry degradation' cannot meaningfully explain variations in communal support for forestry regulations: The leaders concur that forest reserves with the lowest levels of degradation are those whose adjacent communities have been most supportive of forestry regulations throughout the previous twenty years. Thus, the 'extent of forestry degradation' manifests already-failed efforts at supporting forestry regulations, and a suggestion that this manifestation of 'failed support' can explain 'failed support' would raise endogeneity concerns.

I find that, relative to residency in an old village, residency in a camp or a new village is associated with a $146 \%$ and $183 \%$ lesser probability of supporting forestry rules, respectively. And, relative to residency in an old village, residency in a camp or a new village is associated with a $237 \%$ and $209 \%$ lesser probability of trusting that other community members support forestry rules. These associations are statistically significant at the $p<.001$ level (see models 1 and 2). These findings suggest that there is less support for forestry rules in communities that have higher proportions of immigrants, irrespective of those communities' proportions of prospective outmigrants. Relatedly, the findings suggest that there is less trust that other community members support forestry rules in communities with higher proportions of immigrants, irrespective of those communities' proportions of prospective out-migrants. 


\begin{tabular}{|c|c|c|c|}
\hline Variables & Description & Measure/Indicator & $\begin{array}{l}\text { Hypothesized } \\
\text { relationship* }\end{array}$ \\
\hline \multicolumn{4}{|l|}{ Community-level } \\
\hline Residency in a camp & & Binary variable: 1 for yes $\& 0$ for no & - \\
\hline Residency in a new village & & Binary variable: 1 for yes $\& 0$ for no & - \\
\hline Residency in an old village & $\begin{array}{l}\text { The baseline relative to which both camp } \\
\text { and new village are analyzed }\end{array}$ & Binary variable: 1 for yes $\& 0$ for no & \\
\hline Ethnic fractionalization & $\begin{array}{l}\text { The extent of fractionalization along ethnic } \\
\text { lines }\end{array}$ & $\begin{array}{l}\text { Herfindahl index (formally, ELF }=1-\Sigma \text { I } \\
\text { (Proportion of group j) }{ }^{2} \text { ) }\end{array}$ & - \\
\hline $\begin{array}{l}\text { Size of forest reserve(s) } \\
\text { near community }\end{array}$ & & Continuous variable (hectares) & - \\
\hline \multicolumn{4}{|l|}{ Individual-level } \\
\hline Age & & Continuous variable (years) & + \\
\hline Gender & & 1 for men and 0 for women & $+/-$ \\
\hline Source of income & & Binary variable: 1 for farmer $\& 0$ otherwise & $+/-$ \\
\hline Affluence/Poverty & & $\begin{array}{l}\text { Binary variable: } 1 \text { for access to solar } \\
\text { electricity } \& 0 \text { otherwise }\end{array}$ & $+/-$ \\
\hline $\begin{array}{l}\text { Education beyond } \\
\text { secondary }\end{array}$ & & Binary variable: 1 for yes $\& 0$ for no & + \\
\hline Education beyond primary & & Binary variable: 1 for yes $\& 0$ for no & + \\
\hline Duration of residency & Number of years residing in a community & Continuous variable (years) & + \\
\hline Plan to emigrate & $\begin{array}{l}\text { Whether the respondent plans to } \\
\text { emigrate from the local community }\end{array}$ & Binary variable: 1 for yes \& 0 otherwise & - \\
\hline $\begin{array}{l}\text { Spouse or child(ren) } \\
\text { outside the community }\end{array}$ & $\begin{array}{l}\text { Provides a measure of community } \\
\text { attachment }\end{array}$ & Binary variable: 1 for yes $\& 0$ otherwise & - \\
\hline
\end{tabular}

Table 5 Community-level \& Individual-level variables

* The hypothesized relationship is with both the support for forestry rules and the trust that other community members support forestry rules.

Furthermore, relative to residency in an old village, the magnitude of change in support for forestry rules is lower for residency in a new village $(-183 \%)$ than residency in a camp $(-146 \%)$. At the very least, this finding suggests that when a community has a high proportion of immigrants, its low prospects of out-migrating (or its expectation of a more sedentary lifestyle) do not improve the support for forestry rules. The other statistically significant findings include age in model 1 , size of forest reserves in models 1 and 2 and, education beyond secondary school in model 1. A one percent increase in the size of the forest (measured in hectares) leads to $0.1 \%$ less probability of supporting forestry rules and; a respondent who is educated beyond secondary school is $75.5 \%$ more likely to support forestry rules. These findings on age, forest size, and education are corroborated by past research on the determinants of individual attitudes towards community forestry institutions (McKean et al, 2000; Agrawal \& Yadama, 1997).20

I suggest that we take the precise numeric estimates from Table 6 with more than a grain of salt because they imply that when comparing communities whose residents have equally low prospects of out-migrating, residency in a community that has a high proportion of immigrants predicts less support to forestry rules and less trust that others support forestry rules. Additionally, even when comparing two communities that are equally homogeneous in terms of ethnic composition, residency in a community that has a higher proportion of immigrants still predicts less support for forestry rules and less trust that others support forestry rules. ${ }^{21}$

To test the robustness of my findings, I first re-estimated the two models above with two additional control variables to account for (1) the length of time that a respondent has resided in the community and (2) whether the respondent plans to emigrate from the community. I did not include these responses as control variables in the models above due to multicollinearity concerns; that is, the community types are linearly related to a respondent's duration of residency and whether a respondent plans to emigrate from the community. In the re-estimation, I found that the core results of models 1 and 2 in Table 6 are largely the same (See models 3 and 4 in Table 7). The second robustness test involved adding a dummy variable for each of the twelve communities. This helped to control for 


\begin{tabular}{|c|c|c|}
\hline & $\begin{array}{c}\text { Model } 1 \\
\text { (Support forest rules) }\end{array}$ & $\begin{array}{c}\text { Model } 2 \\
\text { (Trust others) }\end{array}$ \\
\hline (Intercept) & $\begin{array}{l}3.663^{* * *} \\
(0.369)\end{array}$ & $\begin{array}{l}4.233^{* * *} \\
(0.232)\end{array}$ \\
\hline $\mathrm{R}$ is a resident of a camp & $\begin{array}{l}-1.467^{* * *} \\
(0.178)\end{array}$ & $\begin{array}{l}-2.371^{* * *} \\
(0.112)\end{array}$ \\
\hline$R$ is a resident of a new village & $\begin{array}{l}-1.838^{* * *} \\
(0.148)\end{array}$ & $\begin{array}{l}-2.098^{* * *} \\
(0.093)\end{array}$ \\
\hline \multicolumn{3}{|l|}{$R$ is a resident of an old village } \\
\hline R has spouse or child(ren) outside community & $\begin{array}{l}-0.013 \\
(0.125)\end{array}$ & $\begin{array}{c}0.081 \\
(0.079)\end{array}$ \\
\hline Ethnic fractionalization in R's community & $\begin{array}{l}-0.046 \\
(0.366)\end{array}$ & $\begin{array}{l}-0.117 \\
(0.230)\end{array}$ \\
\hline Size (ha) of forest reserves near R's community & $\begin{array}{l}-0.001^{*} \\
(0.001)\end{array}$ & $\begin{array}{l}-0.001^{* *} \\
(0.001)\end{array}$ \\
\hline R's age & $\begin{array}{l}0.019 * * \star \\
(0.005)\end{array}$ & $\begin{array}{c}0.001 \\
(0.003)\end{array}$ \\
\hline $\mathrm{R}$ is male & $\begin{array}{c}0.132 \\
(0.112)\end{array}$ & $\begin{array}{l}-0.129 \\
(0.070)\end{array}$ \\
\hline $\mathrm{R}$ is educated beyond primary school & $\begin{array}{c}0.044 \\
(0.113)\end{array}$ & $\begin{array}{l}-0.048 \\
(0.071)\end{array}$ \\
\hline $\mathrm{R}$ is educated beyond secondary school & $\begin{array}{c}0.755^{*} \\
(0.309)\end{array}$ & $\begin{array}{c}0.355 \\
(0.194)\end{array}$ \\
\hline $\mathrm{R}$ is a farmer & $\begin{array}{c}0.194 \\
(0.177)\end{array}$ & $\begin{array}{c}0.041 \\
(0.111)\end{array}$ \\
\hline $\mathrm{R}$ has access to solar electricity & $\begin{array}{l}-0.099 \\
(0.112)\end{array}$ & $\begin{array}{l}-0.050 \\
(0.070)\end{array}$ \\
\hline Number of observations & 293 & 293 \\
\hline
\end{tabular}

Table 6 Predicting support and trust.

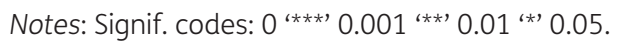

$\mathrm{R}$ means respondent.

Cells contain coefficients from ordered logit regressions with standard errors in parentheses.

community-level fixed-effects and, to explore for possible outliers. The results suggest that the communities within the classification themselves are individually significantly different as predicted by which classification they fall in to.

Taken together (and building on established literature that links social capital to collective action [Ostrom and Ahn, 2009]), the data suggest that 'old villages' are more supportive of forestry rules because their higher proportions of native-born residents are associated with higher levels of communal trust. ${ }^{22}$ Elsewhere, this evidence of a causal connection is corroborated by the qualitative information from the interviews I conducted with community leaders: 29 out of the 52 leaders brought up the 'trust' issue and always linked it to the ongoing forest misappropriation. The situation is summed up concisely in one leader's reflection on his people's social dilemma:

"While we (in Kabubu community) understand that local forests affect our rainfall patterns, it is hard for my people to resist cutting trees because, even if one restrains himself, others will cut the forest... But in the other (communities) where there are many long-term residents, it is easy for them to trust each other."

Furthermore, the above analysis reflects my earlier description of existing attempts at supporting national forestry regulations on Buvuma Island, so much so that one can infer that the local attitudes determine the success of such attempts. Forestry committees (FCs) - which are the only successful local attempts at supporting national regulations- emerge where most communities adjacent to a forest reserve are 'old villages' with lower proportions of immigrants (see Table 1, where the only reserves with FCs- Bira, Buloba, Namabowe, and Nakunyi- are mostly adjacent to 'old villages'). And, collaborative forest organizations (CFOs) - whose existence points to failed local forest governance (as I elaborated earlier) - emerge where most communities adjacent to a forest reserve 


\begin{tabular}{|c|c|c|}
\hline & $\begin{array}{c}\text { Model } 3 \\
\text { (Support for rules) }\end{array}$ & $\begin{array}{c}\text { Model } 4 \\
\text { (Trust others) }\end{array}$ \\
\hline (Intercept) & $\begin{array}{l}3.477^{* * *} \\
(0.364)\end{array}$ & $\begin{array}{l}4.153^{* * *} \\
(0.235)\end{array}$ \\
\hline $\mathrm{R}$ is a resident of a camp & $\begin{array}{l}-0.960^{* * \star} \\
(0.218)\end{array}$ & $\begin{array}{l}-2.361^{* * *} \\
(0.141)\end{array}$ \\
\hline$R$ is a resident of a new village & $\begin{array}{l}-1.318^{* * *} \\
(0.188)\end{array}$ & $\begin{array}{l}-1.981^{* * *} \\
(0.121)\end{array}$ \\
\hline \multicolumn{3}{|l|}{$R$ is a resident of an old village } \\
\hline R's duration of residence (years) in community & $\begin{array}{l}0.025^{* * *} \\
(0.005)\end{array}$ & $\begin{array}{l}0.005 \\
(0.003)\end{array}$ \\
\hline R plans to emigrate from community & $\begin{array}{l}-0.133 \\
(0.169)\end{array}$ & $\begin{array}{c}0.138 \\
(0.109)\end{array}$ \\
\hline R has spouse or child(ren) outside community & $\begin{array}{c}0.001 \\
(0.123)\end{array}$ & $\begin{array}{l}0.066 \\
(0.079)\end{array}$ \\
\hline Ethnic fractionalization in R's community & $\begin{array}{c}0.227 \\
(0.360)\end{array}$ & $\begin{array}{c}0.140 \\
(0.233)\end{array}$ \\
\hline Size (ha) of forest reserves near R's community & $\begin{array}{l}-0.001 \\
(0.001)\end{array}$ & $\begin{array}{l}-0.001^{* *} \\
(0.001)\end{array}$ \\
\hline R's age & $\begin{array}{c}0.002 \\
(0.006)\end{array}$ & $\begin{array}{l}-0.001 \\
(0.004)\end{array}$ \\
\hline $\mathrm{R}$ is male & $\begin{array}{c}0.092 \\
(0.109)\end{array}$ & $\begin{array}{l}-0.131 \\
(0.070)\end{array}$ \\
\hline $\mathrm{R}$ is educated beyond primary school & $\begin{array}{c}0.035 \\
(0.110)\end{array}$ & $\begin{array}{l}-0.050 \\
(0.071)\end{array}$ \\
\hline $\mathrm{R}$ is educated beyond secondary school & $\begin{array}{c}0.752^{*} \\
(0.300)\end{array}$ & $\begin{array}{c}0.370 \\
(0.194)\end{array}$ \\
\hline $\mathrm{R}$ is a farmer & $\begin{array}{c}0.110 \\
(0.173)\end{array}$ & $\begin{array}{c}0.040 \\
(0.112)\end{array}$ \\
\hline $\mathrm{R}$ has access to solar electricity & $\begin{array}{l}-0.106 \\
(0.110)\end{array}$ & $\begin{array}{c}0.037 \\
(0.071)\end{array}$ \\
\hline Number of observations & 293 & 293 \\
\hline
\end{tabular}

Table 7 Predicting support and trust with additional variables.

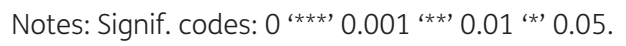

$\mathrm{R}$ means respondent.

Cells contain coefficients from ordered logit regressions with standard errors in parentheses.

are 'camps' and (or) 'new villages', which have higher proportions of immigrants (see Table 1, where the only reserves which have/have had CFOs- Bukaibale, Kakonwa, Olamusa, Bugusa, Kojja, and Sozi - are mostly adjacent to 'camps' and (or) 'new villages').

\section{IMPLICATIONS AND FUTURE RESEARCH}

To examine whether (and why) migrant communities are less likely to support common pool resource institutions, this paper has comparatively analyzed attempts at supporting national forestry regulations in communities that are confronting the degradation of adjacent forest reserves. To avoid a recurrent problem in common pool resource literature, where the relevancy of the findings is often limited to the case under study, special care has been taken to: (1) select an appropriate case study (the case of forest reserve management on Buvuma Island); (2) explicitly specify the causal mechanism; (3) adopt a case-within-case strategy that enables random sampling for sub-cases; and (4) conduct statistical tests so as to examine the causal relationships.

Data from 293 randomly-selected heads of households reveals: (1) less support for forestry regulations in communities with a higher proportion of immigrants, irrespective of the proportion of prospective out-migrants; (2) no significant difference in support for forestry regulations 
between immigrant communities with low prospects of outmigrating (new villages) and transitory communities with high prospects of out-migrating (camps); (3) less trust (that others support the regulations) in communities with higher proportions of immigrants, irrespective of the proportion of prospective out-migrants; and (4) no significant difference in the level of trust between new villages and camps. Taken together, and building on established literature that links social capital to collective action, these findings suggest that the proportion of immigrants and/or prospective outmigrants affects support for forestry regulations through its influence on communal trust.

By implication, the impediments to forestry institutions have more to do with the core communal relationships that are influenced by past migratory behavior than the expectations about institutional net-benefits. This realization is not really original since behavioral patterns (that develop through "past-based" processes) are variously identified by prominent scholars, such as Elinor Ostrom, as prerequisites for overcoming social dilemmas. However, by juxtaposing the influence of such "pastbased" processes with the influence of estimations about institutional benefits, this paper provides the first field study (to my knowledge) about the determinants of institutions for natural resource management that explicitly compares the explanatory powers of interpretations of "past-based" experiences vis-à-vis "future-based" expectations.

Another implication is that, although a new community of immigrants is more likely to oppose common pool resource institutions, in time we should reasonably expect such a community to increasingly support the institutions if its members reside locally (and engage in interactive relationships) for a sufficiently long duration. In other words, the evidence does not point to immigrant status per se as an inhibitor of support for common pool resource institutions: Instead, the short interaction durations among new immigrants imply that their community has not had enough time to develop the core relationships that are necessary to engender collective action for institutional support. Consequently, these findings infer support to public policy that promotes interpersonal interactions so as to overcome common pool resource dilemmas.

This study can be a basis for better examining the determinants of forestry institutional processes among local communities, in addition to guiding analyses of whether the findings are generalizable to other geographical contexts and to issue-domains besides forest reserve governance. Potential advancements of this study could consider (1) land cover change assessments that examine the associations between my community typology and the forest cover change, and (2) 'dynamic evidence' which captures individual attitudes over long periods to examine whether attitudes of migrants actually change over time. Such analyses could extend my findings or, they could very well reveal that the identified relationships are unique to the cases that are studied in this paper. Either way, the scholarly efforts cannot but add to a 'voyage of discovery'.

\section{APPENDIX}

\begin{tabular}{ll}
\hline Type of rule & Description \\
\hline Position rules & $\begin{array}{l}\text { These rules specify the number of possible "positions" that actors in the action situation can assume. The positions in the } \\
\text { forestry committees (FCS) are informal social roles. They include that of an overall chairperson and } 10 \text { to } 15 \text { individuals } \\
\text { who regularly monitor forestry activities. }\end{array}$ \\
\hline Boundary rules & $\begin{array}{l}\text { These rules specify who is eligible to play a role. Some key considerations for FC membership are criminal record, age and, } \\
\text { length of previous residency in the local community. Interestingly, this last consideration suggests local awareness of the } \\
\text { impact of migration on governance schemes. }\end{array}$ \\
\hline Choice rules & $\begin{array}{l}\text { These rules specify what a participant must, must not or may do. The monitors of forestry activities are required to } \\
\text { periodically walk through the reserves and to report illegalities to FC leaders, who in turn are required to ensure that } \\
\text { encroachers are punished. }\end{array}$ \\
\hline $\begin{array}{l}\text { Payoff rules } \\
\text { of a fine, reporting of encroachers to the local police for incarceration and, adopting of norms that ostracize rule breakers. }\end{array}$ \\
\hline $\begin{array}{l}\text { These rules define what actions must, must not or may be taken. For example, FCs define rules that limit their actions } \\
\text { from affecting the only privately managed forest area within the Island's forest reserves, that is, the forest area managed } \\
\text { by Buvuma Palm Resort. }\end{array}$ \\
\hline $\begin{array}{l}\text { These rules determine players' participation in operational-choice decisions. One key aggregation rule found in the FCs is } \\
\text { the requirement that monitoring is done in teams. }\end{array}$ \\
\hline $\begin{array}{l}\text { These rules specify the kinds of information and information channels available. The FCs mostly rely on a voluntary } \\
\text { exchange of information and mutual monitoring. }\end{array}$
\end{tabular}

Table 8 Types of rules utilized by Forestry Committees on Buvuma Island.

Notes: I compiled this information during my preliminary study on Buvuma Island in 2018. 


\begin{tabular}{|c|c|c|c|c|}
\hline Panel A: Data for all respondents & Overall & Camp & Old villages & New villages \\
\hline Proportion of respondents who were born in local community. & $\begin{array}{c}0.25 \\
(0.02)\end{array}$ & $\begin{array}{c}0.04 \\
(0.02)\end{array}$ & $\begin{array}{c}0.72 \\
(0.05)\end{array}$ & $\begin{array}{c}0.00 \\
(0.00)\end{array}$ \\
\hline $\begin{array}{l}\text { Proportion of respondents with spouse and/or child(ren) outside } \\
\text { community. }\end{array}$ & $\begin{array}{c}0.35 \\
(0.03)\end{array}$ & $\begin{array}{c}0.66 \\
(0.04)\end{array}$ & $\begin{array}{c}0.08 \\
(0.03)\end{array}$ & $\begin{array}{c}0.30 \\
(0.05)\end{array}$ \\
\hline Average length of previous residency among community members. & $\begin{array}{l}13.05 \\
(0.93)\end{array}$ & $\begin{array}{l}29.70 \\
(1.76)\end{array}$ & $\begin{array}{c}4.53 \\
(0.35)\end{array}$ & $\begin{array}{c}5.10 \\
(0.60)\end{array}$ \\
\hline $\begin{array}{l}\text { Proportion of respondents who have resided locally for } 3 \text { years or } \\
\text { more. }\end{array}$ & $\begin{array}{c}0.75 \\
(0.02)\end{array}$ & $\begin{array}{c}0.63 \\
(0.04)\end{array}$ & $\begin{array}{c}0.97 \\
(0.02)\end{array}$ & $\begin{array}{c}0.67 \\
(0.05)\end{array}$ \\
\hline $\begin{array}{l}\text { Proportion of respondents who have resided locally for } 5 \text { years or } \\
\text { more. }\end{array}$ & $\begin{array}{c}0.56 \\
(0.03)\end{array}$ & $\begin{array}{c}0.36 \\
(0.05)\end{array}$ & $\begin{array}{c}0.93 \\
(0.03)\end{array}$ & $\begin{array}{c}0.39 \\
(0.05)\end{array}$ \\
\hline $\begin{array}{l}\text { Proportion of respondents who have resided locally for } 10 \text { years or } \\
\text { more. }\end{array}$ & $\begin{array}{c}0.36 \\
(0.03)\end{array}$ & $\begin{array}{c}0.14 \\
(0.03)\end{array}$ & $\begin{array}{c}0.82 \\
(0.04)\end{array}$ & $\begin{array}{c}0.12 \\
(0.03)\end{array}$ \\
\hline Proportion of respondents who plan to emigrate from community. & $\begin{array}{c}0.35 \\
(0.03)\end{array}$ & $\begin{array}{c}0.84 \\
(0.04)\end{array}$ & $\begin{array}{c}0.07 \\
(0.03)\end{array}$ & $\begin{array}{c}0.10 \\
(0.03)\end{array}$ \\
\hline $\begin{array}{l}\text { Proportion of respondents who do not plan to emigrate from } \\
\text { community. }\end{array}$ & $\begin{array}{c}0.54 \\
(0.03)\end{array}$ & $\begin{array}{c}0.08 \\
(0.03)\end{array}$ & $\begin{array}{c}0.87 \\
(0.03)\end{array}$ & $\begin{array}{c}0.76 \\
(0.04)\end{array}$ \\
\hline $\begin{array}{l}\text { Proportion of respondents who are uncertain about emigrating } \\
\text { from community. }\end{array}$ & $\begin{array}{c}0.11 \\
(0.02)\end{array}$ & $\begin{array}{c}0.08 \\
(0.03)\end{array}$ & $\begin{array}{c}0.06 \\
(0.02)\end{array}$ & $\begin{array}{c}0.14 \\
(0.04)\end{array}$ \\
\hline Support for forestry rules (measured on Likert scale) & $\begin{array}{l}3.20 \\
(0.07)\end{array}$ & $\begin{array}{l}2.69 \\
(0.09)\end{array}$ & $\begin{array}{c}4.47 \\
(0.08)\end{array}$ & $\begin{array}{c}2.43 \\
(0.10)\end{array}$ \\
\hline $\begin{array}{l}\text { Trust that others in community support forest rules (measured on } \\
\text { Likert scale) }\end{array}$ & $\begin{array}{c}2.68 \\
(0.07)\end{array}$ & $\begin{array}{c}1.80 \\
(0.04)\end{array}$ & $\begin{array}{c}4.24 \\
(0.06)\end{array}$ & $\begin{array}{c}2.04 \\
(0.07)\end{array}$ \\
\hline Number of observations & 293 & 105 & 97 & 91 \\
\hline \multicolumn{5}{|l|}{ Panel B: Data for respondents who in-migrated to a community } \\
\hline Proportion of immigrants from a place outside Buvuma Island. & $\begin{array}{c}0.97 \\
(0.01)\end{array}$ & $\begin{array}{c}0.96 \\
(0.01)\end{array}$ & $\begin{array}{c}0.93 \\
(0.05)\end{array}$ & $\begin{array}{c}0.98 \\
(0.01)\end{array}$ \\
\hline $\begin{array}{l}\text { Proportion of immigrants who moved individually or as part of } \\
\text { household. }\end{array}$ & $\begin{array}{c}0.99 \\
(0.01)\end{array}$ & $\begin{array}{c}0.98 \\
(0.01)\end{array}$ & $\begin{array}{c}0.96 \\
(0.03)\end{array}$ & $\begin{array}{l}1.00 \\
(0.00)\end{array}$ \\
\hline $\begin{array}{l}\text { Proportion of immigrants who moved to seek better economic } \\
\text { opportunities. }\end{array}$ & $\begin{array}{c}0.92 \\
(0.02)\end{array}$ & $\begin{array}{c}0.93 \\
(0.02)\end{array}$ & $\begin{array}{c}0.89 \\
(0.06)\end{array}$ & $\begin{array}{c}0.91 \\
(0.03)\end{array}$ \\
\hline $\begin{array}{l}\text { Proportion of immigrants who moved due to conflict in place of } \\
\text { origin. }\end{array}$ & $\begin{array}{c}0.03 \\
(0.01)\end{array}$ & $\begin{array}{c}0.03 \\
(0.02)\end{array}$ & $\begin{array}{c}0.00 \\
(0.00)\end{array}$ & $\begin{array}{c}0.03 \\
(0.02)\end{array}$ \\
\hline Proportion of immigrants who moved to follow other relatives. & $\begin{array}{c}0.05 \\
(0.01)\end{array}$ & $\begin{array}{c}0.04 \\
(0.02)\end{array}$ & $\begin{array}{c}0.07 \\
(0.05)\end{array}$ & $\begin{array}{c}0.05 \\
(0.02)\end{array}$ \\
\hline Number of observations & 219 & 100 & 28 & 91 \\
\hline \multicolumn{5}{|l|}{ Panel C: Data for respondents who plan to emigrate from a community } \\
\hline $\begin{array}{l}\text { Proportion of prospective out-migrants whose next place of } \\
\text { residence is outside Buvuma Island }\end{array}$ & $\begin{array}{c}0.99 \\
(0.01) \\
\end{array}$ & $\begin{array}{c}0.99 \\
(0.01) \\
\end{array}$ & $\begin{array}{c}1.00 \\
(0.00) \\
\end{array}$ & $\begin{array}{c}1.00 \\
(0.00)\end{array}$ \\
\hline $\begin{array}{l}\text { Proportion of prospective out-migrants who plan to emigrate } \\
\text { individually or as part of household (but not as part of a large } \\
\text { social group) }\end{array}$ & $\begin{array}{c}1.00 \\
(0.00)\end{array}$ & $\begin{array}{c}1.00 \\
(0.00)\end{array}$ & $\begin{array}{c}1.00 \\
(0.00)\end{array}$ & $\begin{array}{c}1.00 \\
(0.00)\end{array}$ \\
\hline $\begin{array}{l}\text { Proportion of prospective out-migrants whose out-migration is } \\
\text { intended to seek better economic opportunities. }\end{array}$ & $\begin{array}{l}0.25 \\
(0.05)\end{array}$ & $\begin{array}{l}0.20 \\
(0.05)\end{array}$ & $\begin{array}{c}0.57 \\
(0.21)\end{array}$ & $\begin{array}{c}0.44 \\
(0.18)\end{array}$ \\
\hline $\begin{array}{l}\text { Proportion of prospective out-migrants whose out-migration is } \\
\text { intended to seek better public services. }\end{array}$ & $\begin{array}{c}0.09 \\
(0.03)\end{array}$ & $\begin{array}{c}0.08 \\
(0.02)\end{array}$ & $\begin{array}{c}0.14 \\
(0.15)\end{array}$ & $\begin{array}{c}0.11 \\
(0.10)\end{array}$ \\
\hline $\begin{array}{l}\text { Proportion of prospective out-migrants whose out-migration is } \\
\text { intended to return "home" }\end{array}$ & $\begin{array}{c}0.62 \\
(0.04)\end{array}$ & $\begin{array}{c}0.69 \\
(0.05)\end{array}$ & $\begin{array}{c}0.14 \\
(0.15)\end{array}$ & $\begin{array}{c}0.33 \\
(0.17)\end{array}$ \\
\hline Number of observations & 104 & 88 & 7 & 9 \\
\hline
\end{tabular}

Table 9 Selected Means.

Notes: Standard errors are in parentheses. Support for forestry rules and Trust towards other community members are measured as categorical variables on a 5-point Likert scale. All other variables are measured as binary variables with the indicated category taking the value 1 , and 0 otherwise. 


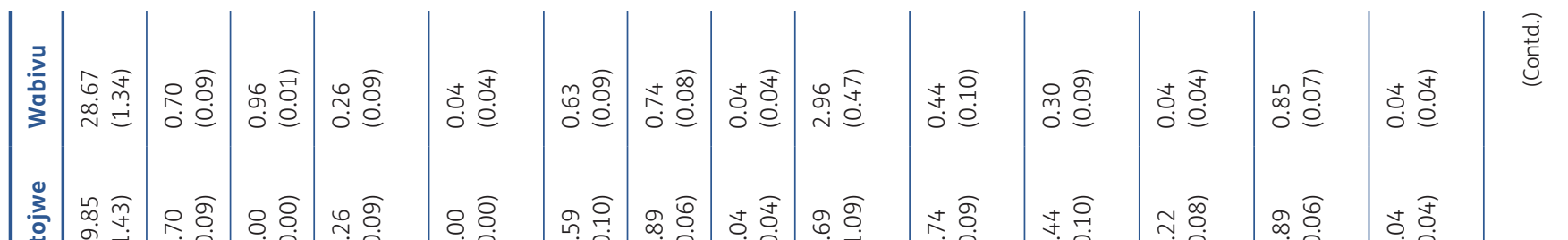

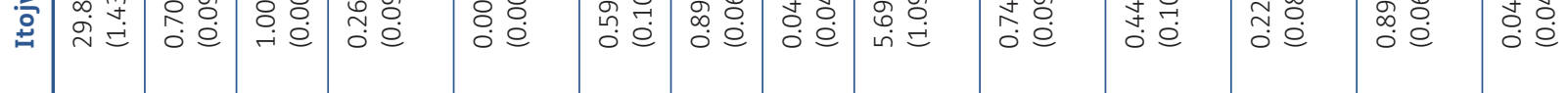

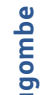

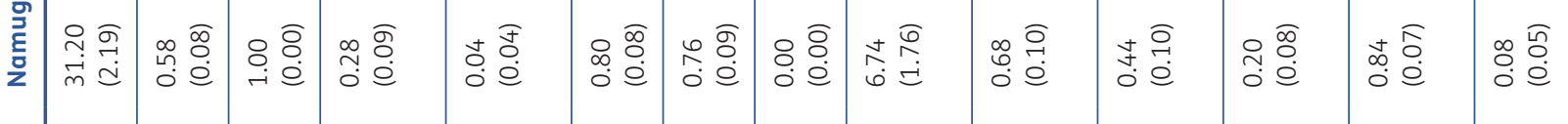

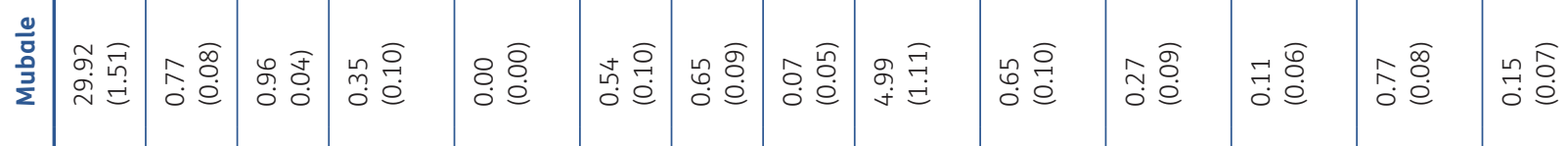

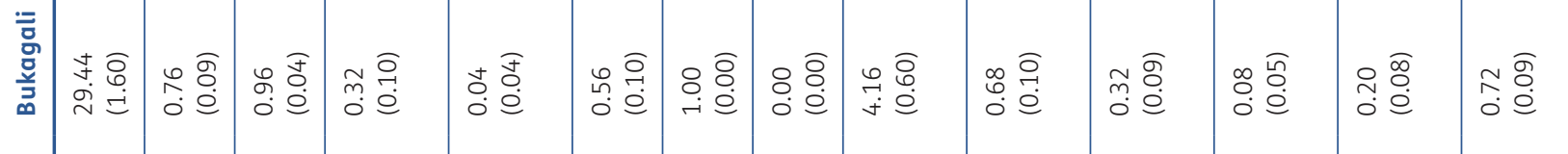

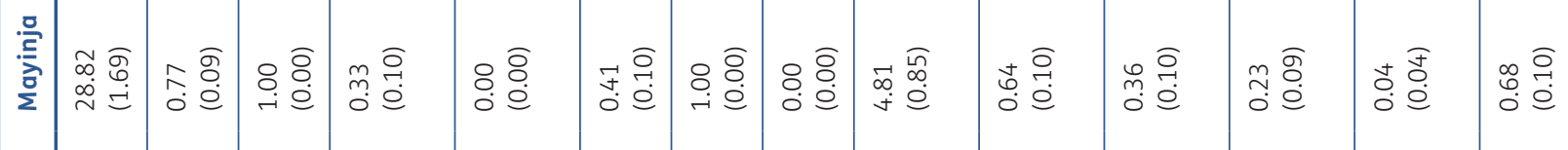

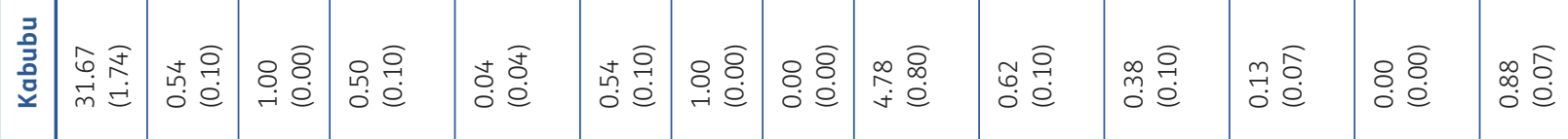

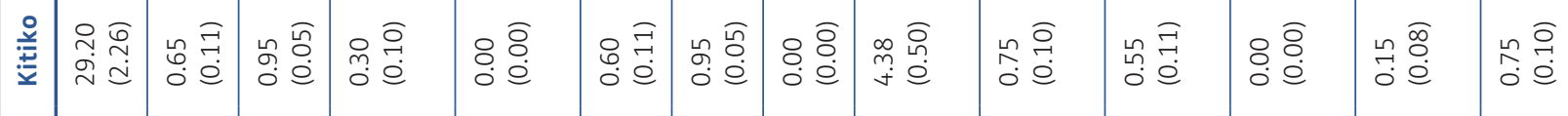

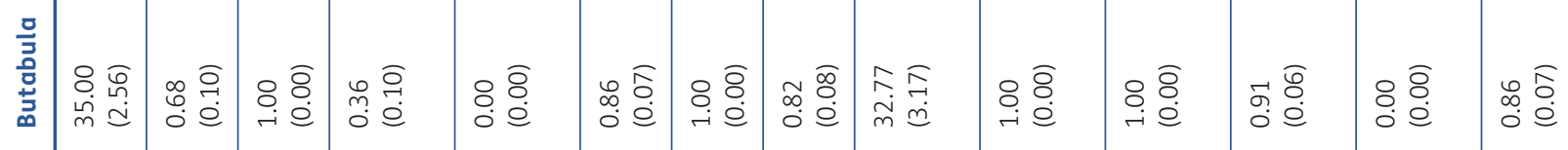

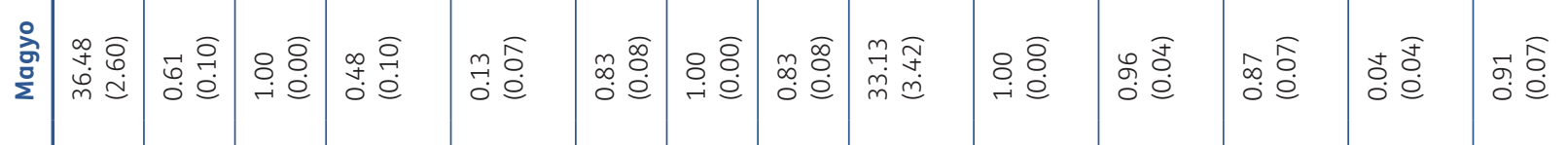

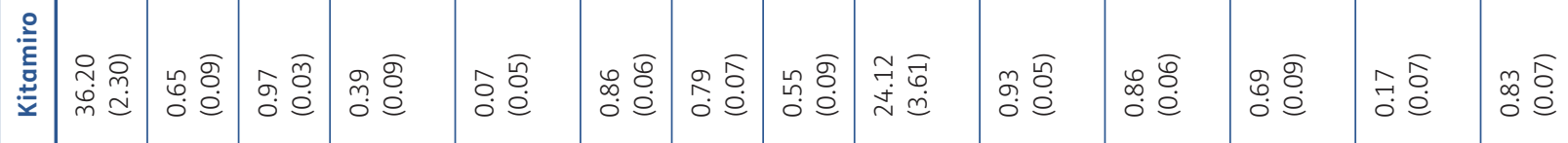

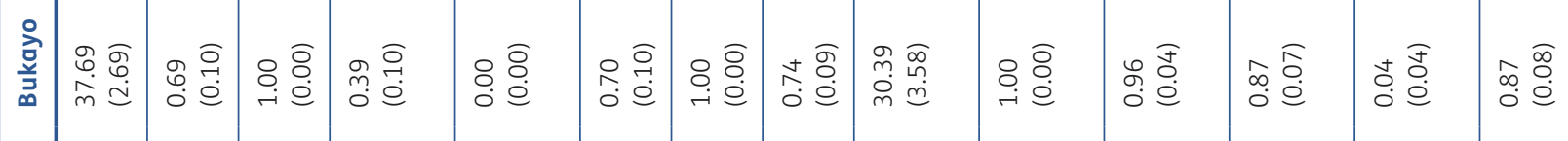

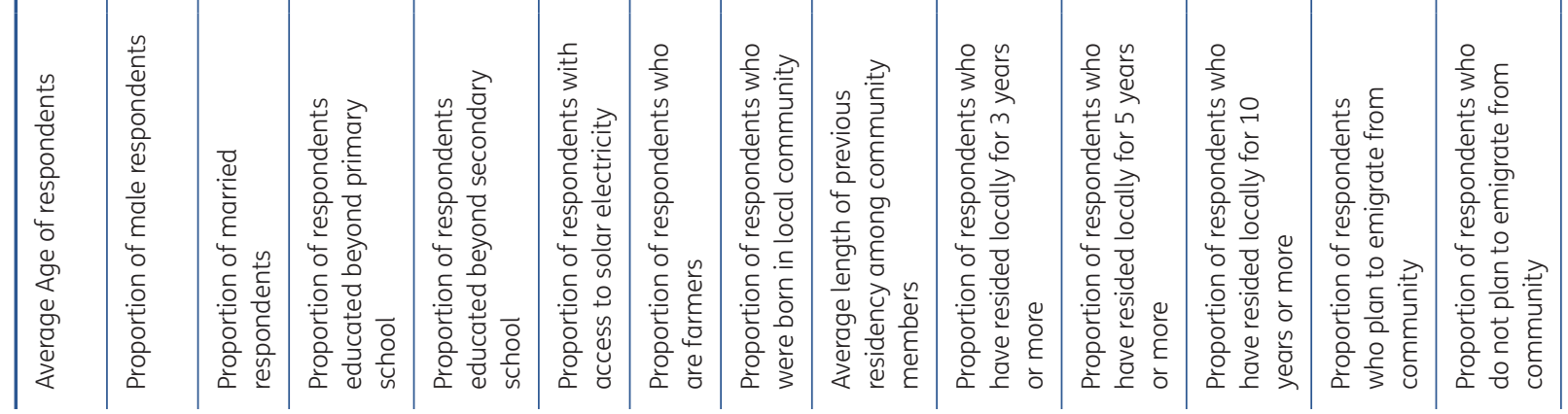




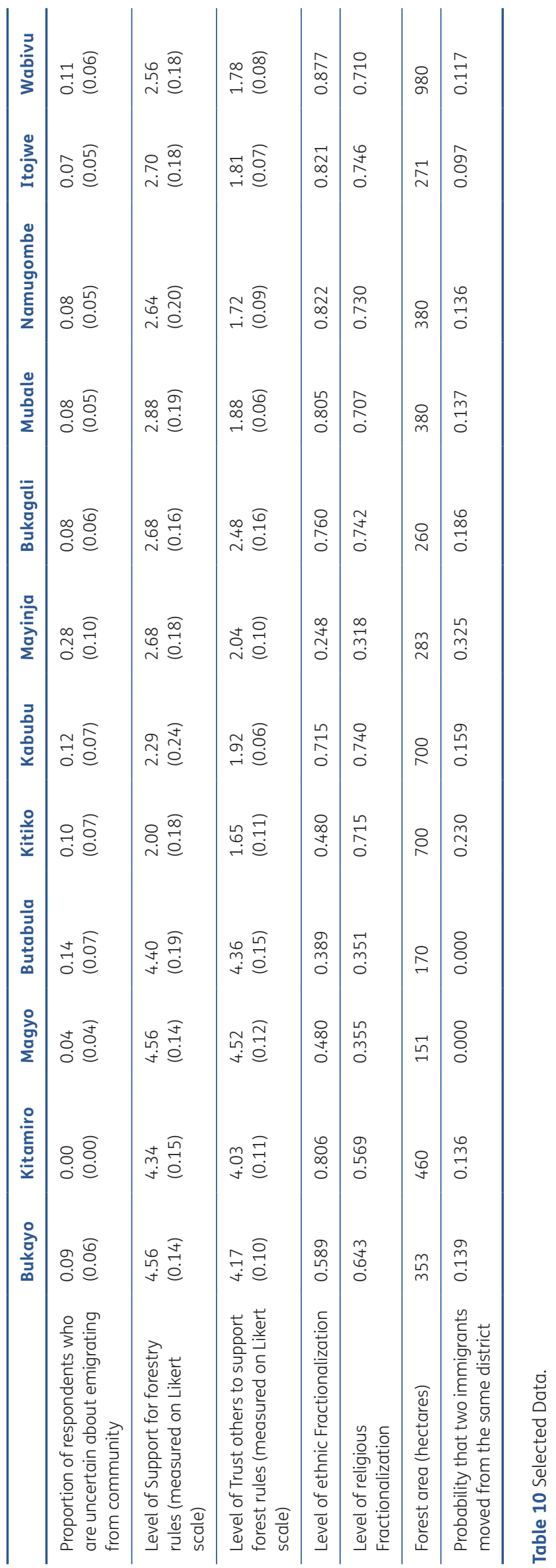




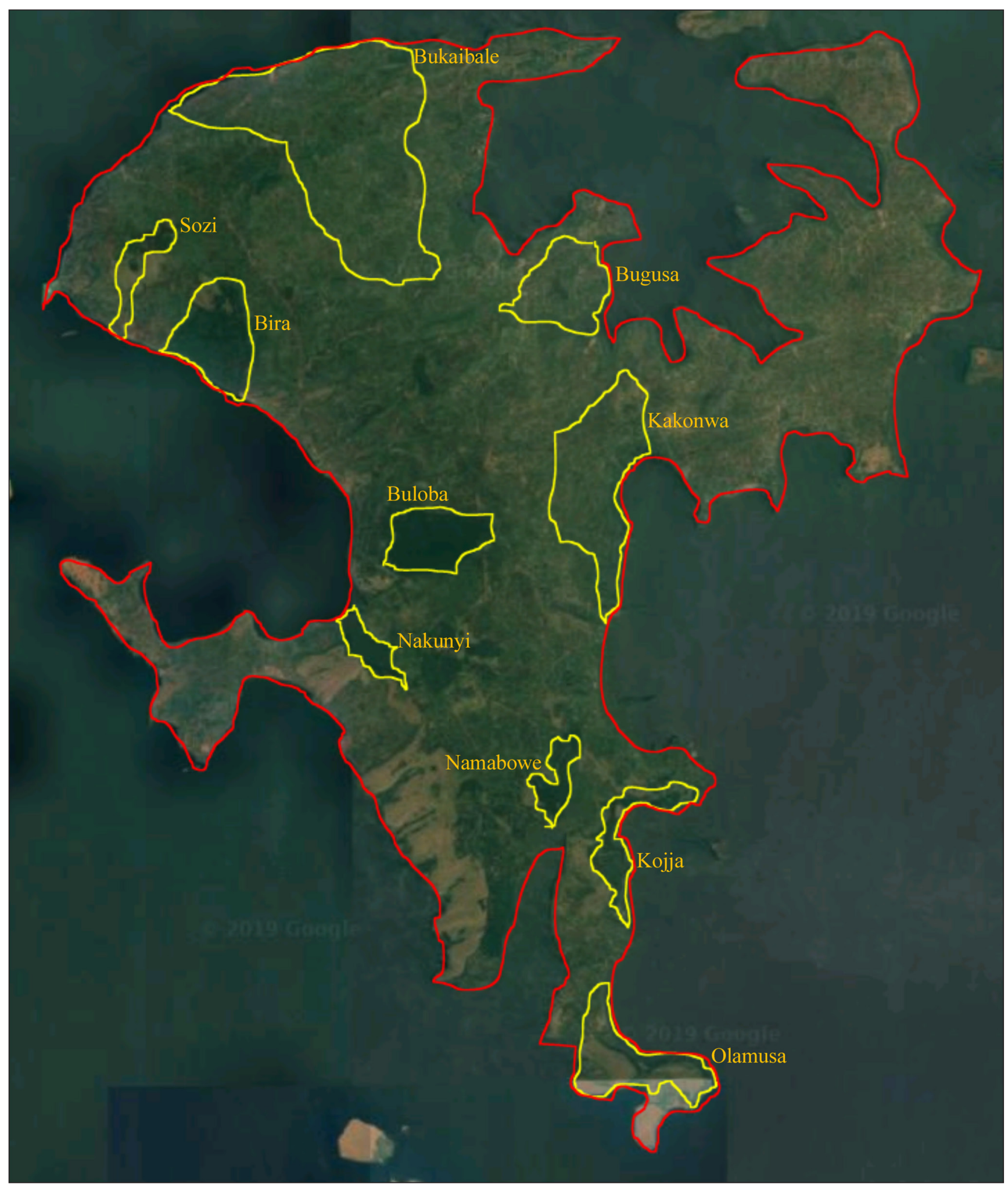

Figure 8 Some forest reserves on Buvuma Island.

Source: Google Maps October 2019 (the forest reserve parameters are sketched by the author)

Notes: Although a proper land-cover study necessitates advanced geographical analysis techniques (such as those availed by GIS), a casual look at the Google Map of Buvuma Island reveals that, of the ten forest reserves under study, the shade of green is darker in some. Importantly, these differences between the colors tend to reflect the estimations made by the NFA officials. 


\section{NOTES}

1 Hitherto, few studies have considered this question. Even the well-known studies by Ostrom, Agrawal, Baland, and Wade have not explicitly considered institutional processes in migrant communities (Ostrom, 1990; Agrawal, 2001; Baland \& Platteau, 1996; Wade, 1987).

2 While this literature largely focuses on the effects of flow rates (of migration) on communal processes, the present study considers the potential for institutions among migrant communities. That said, by identifying how migration affects collective action through social capital, the same literature provides a basis for the present study's emphasis on the role of communal relationships (of reputation, trust, and reciprocity) in institutional processes among migrant communities.

3 I adopt the Uganda National Household Survey's definition of migration as the geographic movement of individuals (or households) across a specified boundary- which in my study is a local community- to reside in the new locality for a period of not less than six months (Uganda National Household Survey, 2017: 29). Thus, migration is carefully distinguished from mobility, which refers to the more fluid movements of people in the course of their daily lives.

4 Away from field research, some game-theoretical studies compare these explanatory powers. For example, Acemoglu and Jackson (2015) compare backward-looking societies (where equilibrium play is completely driven by history, or agents' interpretations of information about the past) with more forward-looking societies (where expectations about the future limit the influence of history).

5 Frontiers are areas not previously used or occupied that are subsequently put to use by new settlers.

6 The focus on communal interactions and social trust does not mean that there are no other mechanisms through which migration may be relevant to collective action for common pool resource management. Instead, this focus was largely inspired by the information I gathered during preliminary field research, which suggested no other mechanism that is as important. Moreover, the complexity of the context under study makes it necessary to isolate one realm for systematic analysis, instead of undertaking the unfeasible task of considering all potential mechanisms simultaneously.

7 Buvuma Island should not be confused with Buvuma Islands, a chain of several Islands.

8 This fact presents a puzzle that needs a separate research study to reconcile. That is, assuming that the proportion of immigrants has varied among Buvuma's communities for several decades, why is the "unprecedented" forest destruction documented for only the last 20 years? In other words, if the relation between immigrant composition and support for resource management institutions were unilinear over time, we should expect permanent differences between forest governance outcomes such that communities with high proportions of immigrants should have destroyed adjacent forest reserves even before the year 2000. A possible solution might require considering whether transaction costs moderate the impact of migration on forestry institutional processes (Ssekajja, Working Paper). For example, just between 2009 and 2011, charcoal prices in Uganda rose by $140 \%$ (Otoo \& Drechsel, 2018:73). It could be that such a rise in prices increased both the benefits of forestry destruction and the costs of institutional processes.

9 During preliminary research, I used Ostrom's (2005) Institutional Analysis and Development framework to gain a deeper understanding of FC forestry rules on Buvuma Island (see Appendix, Table 8).

10 First, the existence of a CFO is itself an indicator of failed forest governance: the NFA only authorizes CFOs in forest reserves that are already severely degraded. Second, CFO operations reveal only a tangential concern with forest conservation: to encourage local participation, the NFA permits CFO members to engage in certain agricultural activities on forest reserve land, as long as they also plant trees. Consequently, to most locals, the main value of a CFO is not forest conservation; instead, it avails rights to land for agricultural production. No wonder, because those rights last until the planted trees mature, there are many reported cases of CFO members sabotaging the maturation of trees or cutting them down when mature. In fact, the NFA has dissolved CFOs in Bukaibale and Kakonwa, in addition to threatening all other CFOs with dissolution, due to such destructive activities.

11 These local leaders are elected democratically in elections that are organized by the Ugandan central government.

12 To ensure sufficient variation on the factors under consideration, I focused on communities that heightened the contrast between high and low proportions of migrants. This approach excludes 12 communities with intermediate proportions of migrants.

13 This classification has almost nothing to do with the seasonal mobility of fishers in Lake Victoria that is variously studied (Nunan, 2010; Allison \& Ellis, 2001). To elaborate, there are some residents of Buvuma Island's communities who sometimes move temporarily to other communities to seek fish and, there are some residents of communities beyond Buvuma Island who sometimes move temporarily to Buvuma Island to seek fish. But this seasonal mobility is not prevalent among the residents of Buvuma Island. And, the mobile fishers to Buvuma Island always have a "community of residence" they return to when fish stocks in waters around Buvuma Island decline. They settle temporarily in "host" communities on Buvuma Island, usually for a period of no more than one month. Because they are temporarily hosted, they are not migrants (as per the definition of migration in the introduction of this article). Also, they usually do not establish housing structures of their own in the "host" communities, especially because they catch fish at night and spend most of the day sleeping under trees. They tend to constitute a very small proportion of the "host" community population and, importantly, they have rather negligible interest in appropriating forestry resources in the "host" communities. Thus, their role in local forestry governance can be safely sidelined: I suggest that studying them could be more useful for understanding their impact on other local socio-economic dynamics such as fisheries management, food market supplies, sex trade, and public sanitation.

14 Nevertheless, there are many residents of camps who are natives and who never consider emigrating.

15 The process of random selection involved blindly selecting a name of a community from a list until a large enough sample was collected.

16 One potential alternative explanation that I sideline is the "oil palm project on Buvuma Island", which was in its planning stages during my field trips. None of the interviewed local leaders suggested that this planned project had had a noticeable impact on the institutional processes for forest reserve management. Moreover, the community relocations (to prepare land for the project) never extended to any of my sampled communities. Nevertheless, although I have no reason to assume that the project (in its planning phase) affected forestry management processes in the communities I studied, future research could find that, once the project kicked off, it significantly affected those processes.

17 To my knowledge, this is the first community/village level estimation of the number of households on Buvuma Island. The most approximate existing data considers parish level figures, rather than the villages that make up those parishes (See Buvuma District Hazard, Risk and Vulnerability Profile, 2016).

18 of the several interrelated core communal relationships that I mentioned in the introduction, the survey focused on trust. Thus, I omitted the core communal relationships of reputation and reciprocity. The omission became necessary because, given the limitations of my case study, I found it very difficult to measure "reputation" and "reciprocity".

19 The formula for this probability is adapted from the Herfindhal index $[=\Sigma$ I (Proportion of immigrants that migrated from a district) ${ }^{2}$ ]. The data suggests that most immigrants did not move from the same geographical district of origin. Thus, it is less likely that the new community developed relationships of reputation, trust, and reciprocity before moving. When analyzing this data I made a slight adjustment: for the very few respondents who immigrated either from another community on Buvuma Island or from a country outside Uganda, I considered that community or country, instead of district. 
20 That said, these findings suggest that education only affects attitudes towards forestry rules only when an individual is educated up-to secondary school.

21 A more detailed comparative analysis of the influences of ethnic diversity and immigration on institutional processes is provided by Ssekajja (Working Paper).

22 In other words, the proportion of migrants (immigrants and/or prospective out-migrants) has no direct influence on the level of support for forestry regulations; but rather, it affects the functional mechanism of other variables that are necessary to engender such support.

\section{ACKNOWLEDGEMENTS}

I would like to express my gratitude to Daniel H. Cole, William K. Winecoff, Eduardo S. Brondizio and Landon Yoder for their guidance and helpful comments. I am equally grateful to Sergio Villamayor-Tomas and the anonymous reviewers at International Journal of the Commons. Kintu Philemon also deserves special thanks for the assistance he provided during my field research on Buvuma Island.

\section{COMPETING INTERESTS}

The author has no competing interests to declare.

\section{AUTHOR AFFILIATION}

Godfreyb Ssekajja (D) orcid.org/0000-0001-6566-6290

Indiana University Bloomington, USA

\section{REFERENCES}

Acemoglu, D., \& Jackson, M. O. (2015). History, expectations, and leadership in the evolution of social norms. The Review of Economic Studies, 82(2), 423-456. DOI: https://doi. org/10.1093/restud/rdu039

Agrawal, A. (2001). Common property institutions and sustainable governance of resources. World development, 29(10), 16491672. DOI: https://doi.org/10.1016/S0305-750X(01)00063-8

Agrawal, A., \& Yadama, G. (1997). How do local institutions mediate market and population pressures on resources? Forest Panchayats in Kumaon, India. Development and change, 28(3), 435-465. DOI: https://doi.org/10.1111/1467-7660.00050

Allison, E. H., \& Ellis, F. (2001). The livelihoods approach and management of small-scale fisheries. Marine policy, 25(5), 377-388. DOI: https://doi.org/10.1016/S0308597X(01)00023-9

Alston, L. J., Harris, E., \& Mueller, B. (2012). The development of property rights on frontiers: endowments, norms, and politics. The Journal of Economic History (pp. 741-770). DOI: https:// doi.org/10.1017/S0022050712000356
Alston, L. J., Libecap, G. D., \& Schneider, R. (1996). The demand and supply of property rights on the frontier: The cases of North America and Brazil. The Privatization Process; A Worldwide Perspective, (pp. 203-36).

Amacher, G. S., Koskela, E., \& Ollikainen, M. (2009). Deforestation and land use under insecure property rights. Environment and Development Economics, 14(3), 281-303. DOI: https://doi. org/10.1017/S1355770X0800483X

Anderson, T. L., \& Hill, P. J. (2004). The not so wild, wild west: Property rights on the frontier. Stanford University Press.

Andersson, K. P. (2004). Who talks with whom? The role of repeated interactions in decentralized forest governance. World Development, 32(2), 233-249. DOI: https://doi. org/10.1016/j.worlddev.2003.07.007

Angelson, A. (1999). Agricultural Expansion and Deforestation: Modeling the Impact of Population, Market Forces, and Property Rights. Journal of Development Economics, 58, 185218. DOI: https://doi.org/10.1016/S0304-3878(98)00108-4

Baland, J. M., \& Platteau, J. P. (1996). Halting degradation of natural resources: is there a role for rural communities? Food $\&$ Agriculture Org.

Bilsborrow, R. E. (2002). Migration, population change, and the rural environment. Environmental change and security project Report, 8(1), 69-84.

Buvuma District Hazard, Risk and Vulnerability Profile. (2016). Available at <https://www.necoc-opm.go.ug/HzCentral2/ Buvuma\%20District\%20HRV\%20Profile.pd>

Clay, K., \& Wright, G. (2005). Order without law? Property rights during the California gold rush. Explorations in Economic History, 42(2), 155-183. DOI: https://doi.org/10.1016/j. eeh.2004.05.003

Clay, K., \& Wright, G. (2011). Gold rush legacy: American minerals and the knowledge economy.

Cole, D. H., \& Ostrom, E. (2012). Property in Land and Other Resources (edited by Daniel H. Cole and Elinor Ostrom). Lincoln Institute of Land Policy.

Curran, S. R., \& Agardy, T. (2002). Common property systems, migration, and coastal ecosystems. AMBIO: A Journal of the Human Environment, 31(4), 303-305. DOI: https://doi. org/10.1579/0044-7447-31.4.303

De Janvry, A., Emerick, K., Gonzalez-Navarro, M., \& Sadoulet, E. (2015). Delinking land rights from land use: Certification and migration in Mexico. American Economic Review, 105(10), 3125-49. DOI: https://doi.org/10.1257/aer.20130853

Hepworth, N., \& Goulden, M. (2008). Climate Change in Uganda: Understanding the implications and appraising the response.

Katz, E. G. (2000). Social capital and natural capital: a comparative analysis of land tenure and natural resource management in Guatemala. Land economics (pp. 114-132). DOI: https://doi.org/10.2307/3147261

Matsuishi, T., Muhoozi, L., Mkumbo, O., Budeba, Y., Njiru, M., Asila, A., Othina, A., \& Cowx, I. G. (2006). Are the exploitation 
pressures on the Nile perch fisheries resources of Lake Victoria a cause for concern? Fisheries Management and Ecology, 13(1), 53-71. DOI: https://doi.org/10.1111/j.13652400.2006.00477.x

McDowell, A. G. (2002). From commons to claims: property rights in the California Gold Rush. Yale JL \& Human, 14, 1.

McKean, C. C. G. M. A., \& Ostrom, E. (2000). People and forests: Communities, institutions, and governance. MIT Press.

Mulley, B. G., \& Unruh, J. D. (2004). The role of off-farm employment in tropical forest conservation: labor, migration, and smallholder attitudes toward land in western Uganda. Journal of Environmental Management, 71(3), 193205. DOI: https://doi.org/10.1016/j.jenvman.2004.02.002

Nangendo, G. (2018). Land use changes (1990-2015) in Kalangala and Buvuma districts, southern Uganda. Land use changes (1990-2015) in Kalangala and Buvuma districts, southern Uganda (pp. 14-21).

Nunan, F. (2010). Mobility and fisherfolk livelihoods on Lake Victoria: Implications for vulnerability and risk. Geoforum, 41(5), 776-785. DOI: https://doi.org/10.1016/j.geoforum.2010.04.009

Ostrom, E. (1990). Governing the commons: The evolution of institutions for collective action. Cambridge university press. DOI: https://doi.org/10.1017/CB09780511807763

Ostrom, E. (1999). Self-governance and forest resources. Terracotta reader: A market approach to the environment, 12. DOI: https://doi.org/10.17528/cifor/000536

Ostrom, E. (2000). Collective action and the evolution of social norms. Journal of economic perspectives, 14(3), 137-158. DOI: https://doi.org/10.1257/jep.14.3.137

Ostrom, E. (2005). Understanding institutional diversity. Princeton university press. DOI: https://doi.org/10.1515/9781400831739

Ostrom, E. (2010). Analyzing collective action. Agricultural economics, 41, 155-166. DOI: https://doi.org/10.1111/j.15740862.2010.00497.x

Ostrom, E., \& Ahn, T. K. (2009). The meaning of social capital and its link to collective action. Handbook of social capital: The troika of sociology, political science and economics (pp. 17-35).

Ostrom, E., Gardner, R., Walker, J., Walker, J. M., \& Walker, J. (1994). Rules, games, and common-pool resources. University of Michigan Press. DOI: https://doi.org/10.3998/mpub.9739

Otoo, M., \& Drechsel, P. (2018). Resource recovery from waste: business models for energy, nutrient and water reuse in lowand middle-income countries. Routledge. DOI: https://doi. org/10.4324/9781315780863

Pagdee, A., Kim, Y. S., \& Daugherty, P. J. (2006). What makes community forest management successful: a meta-study from community forests throughout the world. Society and Natural resources, 19(1), 33-52. DOI: https://doi. org/10.1080/08941920500323260

Pretty, J., \& Ward, H. (2001). Social capital and the environment. World development, 29(2), 209-227. DOI:
https://doi.org/10.1016/S0305-750X(00)00098-X

Robson, J., \& Berkes, F. (2011). How does out-migration affect community institutions? A study of two indigenous municipalities in Oaxaca, Mexico. Human Ecology, 39(2), 179190. DOI: https://doi.org/10.1007/s10745-010-9371-x

Rudel, T. (2011). The commons and development: unanswered sociological questions. International Journal of the Commons, 5(2). DOI: https://doi.org/10.18352/ijc.248

Shively, G. E. (2002). Agricultural Change, Rural Labor markets, and Forest Clearing: An Illustrative Case from the Philippines. Land Economics, 77, 268-284. DOI: https://doi. org/10.2307/3147094

Silsbe, G., Kolding, J., Van Zwieten, P., Mkumbo, O., \& Hecky, R. (2008). Are the Lake Victoria fisheries threatened by exploitation or eutrophication? Towards an ecosystembased approach to management. The ecosystem approach to fisheries (pp. 309-354). DOI: https://doi. org/10.1079/9781845934149.0309

Ssekajja, G. (Working Paper). Does Immigration Explain Why Ethnic Diversity Is Negatively Associated With Collective Action?

Ssekajja, G. (Working Paper). Immigration, Ethnic Diversity and Public Goods Provisioning: Evidence from Rural Communities in Uganda.

Timbuka, M. F. (2018). "Assessing the impact of oil palm expansion on the ecosystem services under different scenarios. A case of Buvuma Island, Uganda."

Uganda National Household Survey. (2017). Uganda Bureau of Statistics. Available at <https://www.ubos.org/onlinefiles/ uploads/ubos/pdf\%20documents/UNHS_VI_2017_ Version_I_\%2027th_September_2017.pdf>

Umbeck, J. R. (1981). A theory of property rights: With application to the California gold rush. Iowa State Press.

Wade, R. (1987). The management of common property resources: collective action as an alternative to privatization or state regulation. Cambridge journal of economics, 11(2), 95-106. DOI: https://doi.org/10.1093/oxfordjournals.cje.a035024

Wandiga, S. O., Opondo, M., Olago, D., Githeko, A., Githui, F., Marshall, M., Downs, T., Opere, A., Oludhe, C., Ouma, G. O., \& Yanda, P. Z. (2010). Vulnerability to epidemic malaria in the highlands of Lake Victoria basin: the role of climate change/ variability, hydrology and socio-economic factors. Climatic Change, 99(3-4), 473-497. DOI: https://doi.org/10.1007/ s10584-009-9670-7

Wang, Y., Chen, C., \& Araral, E. (2016). The effects of migration on collective action in the commons: Evidence from rural China. World Development, 88, 79-93. DOI: https://doi. org/10.1016/j.worlddev.2016.07.014

Zerbe, R. 0., \& Anderson, C. L. (2001). Culture and fairness in the development of institutions in the California gold fields. The Journal of Economic History, 61(1), 114-143. DOI: https://doi. org/10.1017/S0022050701025062 
TO CITE THIS ARTICLE:

Ssekajja, G. (2021). Commons Management in Migrant Communities. International Journal of the Commons, 15(1), pp. 132-153. DOI: https://doi.org/10.5334/ijc.1079

Submitted: 18 September 2020 Accepted: 03 March 2021 Published: 14 May 2021

COPYRIGHT:

(C) 2021 The Author(s). This is an open-access article distributed under the terms of the Creative Commons Attribution 4.0 International License (CC-BY 4.0), which permits unrestricted use, distribution, and reproduction in any medium, provided the original author and source are credited. See http://creativecommons.org/licenses/by/4.0/.

International Journal of the Commons is a peer-reviewed open access journal published by Ubiquity Press.

\section{]u[ ə}

